\title{
Parametric Rietveld Refinement Applied to In-Situ Monitoring of X-Ray Powder Diffraction Data of Plaster Hydration
}

\author{
Heloísa Cristina Fernandes Cordon ${ }^{a, b} *_{\mathbb{C}}$, Fabio Furlan Ferreira $^{b}{ }^{(\mathbb{C}}$ \\ ${ }^{a}$ Engenharia Civil, Instituto Mauá de Tecnologia, São Caetano do Sul, SP, Brasil \\ ${ }^{b}$ Centro de Ciências Naturais e Humanas, Universidade Federal do ABC, Santo André, SP, Brasil
}

Received: December 12, 2018; Revised: November 21, 2019; Accepted: January 10, 2020

\begin{abstract}
The recycling of civil construction waste gypsum has been the subject of studies due to the nonexistence of economically viable technologies or applications that would allow it to be recycled. However, studies indicate that the material setting time reduces after recycling, generating more waste, but the cause of the phenomenon is not known. In-situ XRPD monitoring of plasters' hydration in their commercial form and after laboratory recycling process is carried out to verify both reactivity and hydration process. The samples are characterized by specific surface area, microporosity, and consistency tests. Sequential and parametric Rietveld refinements are employed to determine the weight fractions of calcium sulfate-based compounds present in the materials as a function of time. The increase in the consistency of the recycled plaster is not only associated with the increase of microporosity and specific surface area but also to the instant formation of gypsum as soon as the material comes into contact with water. These data also confirm the increase in the kinetic activity values calculated from the results of temperature kinetics tests, proving that the formation of hydrated compounds is much faster for the recycled plaster, which is associated with the increase of water contact area.
\end{abstract}

Keywords: Recycling of gypsum waste, in-situ monitoring, plaster hydration.

\section{Introduction}

Gypsum finds its most significant application in the construction industry, in the form of plaques, decorative elements, and pastes for coating, although it can also be used in the manufacture of molds for the ceramic, metallurgical and plastics industries, in orthopedic and dental molds, in agriculture and several other applications. Due to its short useful life for use after mixing with water, known as setting time, gypsum used as a coating in civil construction generates a significant amount of waste ${ }^{1}$. According to Godinho-Castro et al. ${ }^{2}$, gypsum is the second most abundant constituent of residential construction and demolition waste (CDW), leaving behind only ceramic materials, and the importance of its recycling has grown with increasing demand for sustainable building practices. However, Ângulo et al. ${ }^{3}$ state that the presence of a high volume of gypsum in CDW can be a complication for the recycling of this waste if control processes are not incorporated in the recycling centers. The presence of gypsum limits the application of the recycled aggregates from CDW, since the reaction between the cement aluminates and the gypsum sulfate, when in the presence of water, leads to the formation of ettringite, a compound whose volume is higher than the original reagents, generating expansive tensions that disintegrate concrete parts. Therefore, the maximum sulfate content in the aggregates is limited by $1 \%$ in most standards ${ }^{1,4,5}$.

Due to its water-solubility characteristic, the presence of gypsum in landfills causes long-term problems due to leaching, which may affect the composition and $\mathrm{pH}$ of

*e-mail: heloisa.cordon@gmail.com the water and soil ${ }^{1}$. Other conditions present in landfills and dumps, such as humidity, low $\mathrm{pH}$, and the presence of sulfate-reducing bacteria, lead to the formation of the sulfide gas $\left(\mathrm{H}_{2} \mathrm{~S}\right)$, which is toxic and flammable ${ }^{6,7}$.

By mid-2011, in Brazil, gypsum waste from construction and demolition was defined as non-recyclable because it fell into the "C" class according to Resolution 307/2000 of the National Council of Environment (CONAMA, Brazil ${ }^{8}$ ), due to the non-existence of economically viable technologies or applications that would allow it to be recycled or recovered. With the publication of Resolution 431/2011 of CONAMA ${ }^{9}$, gypsum waste was considered recyclable, since its classification was changed to category " $\mathrm{B}$ ".

Since gypsum-containing residues are easily recycled, by simply calcining them with low energy consumption and rehydrating them to obtain new gypsum products, the gypsum segment presents an excellent potential for contribution to the sustainability of the construction industry ${ }^{1,10,11}$. Although international experiences in the USA and in some European countries show the feasibility of recycling gypsum waste in the flat-bed processing sector, in Brazil, this process is practically non-existent, with few isolated initiatives and incipient research ${ }^{11}$. As the demand for the use of gypsum in the Brazilian construction industry has been increasing without the surveillance of suitable technologies for its recycling, this subject deserves much attention ${ }^{12}$.

Despite the advantages of the recycling process, it is believed that recycled gypsum presents even less setting time than natural gypsum, which would probably increase the waste of this material ${ }^{13}$. Thus, it becomes 
crucial to study and characterize the recycled gypsum microstructure for better understanding and controlling this phenomenon.

\section{Literature Review}

\subsection{Plaster hydration}

Karni and $\mathrm{Karni}^{14}$ define gypsum as a cementitious material that hardens in the presence of air, but its crystallization and complete hardening occur by reaction with water, although it does not withstand moisture after hardened because it is soluble. In the gypsum hydration process, the anhydrous material reacts with water initially forming hemihydrates by the reaction of the anhydrite III with water, according to (1), and later regenerating the calcium sulfate dihydrate, according to $(2)^{15}$.

$$
\begin{gathered}
\underbrace{\mathrm{CaSO}_{4}}_{\text {anhydrite }}+0.5 \mathrm{H}_{2} \mathrm{O} \rightarrow \underbrace{\mathrm{CaS \textrm {SO } _ { 4 }} \cdot 0.5 \mathrm{H}_{2} \mathrm{O}}_{\text {hemingyrate }}+\Delta H<0 \\
\underbrace{\mathrm{CaS \textrm {O } _ { 4 }} \cdot 0.5 \mathrm{H}_{2} \mathrm{O}}_{\text {hemilydrate }}+1.5 \mathrm{H}_{2} \mathrm{O} \rightarrow \underbrace{\mathrm{CaSO_{4 }} \cdot 2 \mathrm{H}_{2} \mathrm{O}}_{\text {dihydrate }}+\Delta H<0
\end{gathered}
$$

The hydration process starts when the two materials are in contact, forming a homogeneous paste that acquires consistency quickly and solidifies until it hardens, i.e., the moment when the material starts to present mechanical resistance ${ }^{11}$.

The gypsum hydration mechanism was studied from two perspectives: the crystallization theory and the colloidal theory. Antunes ${ }^{16}$ and Pinheiro ${ }^{11}$ state in their research that the crystallization theory was more consistent and was then adopted by most researchers. The gypsum hydration process is exothermic, i.e., the hydration reactions release heat. If hydration occurs under adiabatic conditions, the temperature increment $(\Delta T)$ will be proportional to the amount of calcium sulfate dihydrate formed, revealing the kinetics of the reactions. The total heat generated in the reaction is due to the dissolution process of the hemihydrate. Calorimetric tests that measure the amount of heat released over time allow the identification of different stages of gypsum hydration, such as dissolution, induction, growth of the crystallization nuclei, and reduction of reactions ${ }^{10,15,17,18}$. Lewry and Williamson ${ }^{15}$ used a simple calorimeter with a thermocouple inserted in the sample to measure the temperature variation $(\Delta T)$ as a function of time of a gypsum sample during hydration. The kinetics of the hydration reactions is a function of the content of the compounds present in the gypsum and their respective reactivities since the anhydrites have different reaction rates between them and to the hemihydrate. The presence of impurities, such as non-calcined dihydrates, accelerates hydration reactions and reduces the setting time since they act as crystallization nuclei $i^{10,18-21}$.

\subsection{Recycling of gypsum waste}

Since the transformation reactions of gypsum into plaster (hemihydrate) by calcination, and from the plaster into dihydrate (product of the same composition that originated it) through hydration are reversible (3), the recycling of plaster residue is easily performed, according to Cordon ${ }^{22}$, resulting in a product with binder properties ${ }^{1,11}$.

$$
\underbrace{\mathrm{CaSO}_{4} \cdot 2 \mathrm{H}_{2} \mathrm{O}}_{\text {dihydrate }}+\Delta \mathrm{H}<0 \longleftrightarrow \underbrace{\mathrm{CaSO}_{4} \cdot 0.5 \mathrm{H}_{2} \mathrm{O}}_{\text {heminydrate }}+1.5 \mathrm{H}_{2} \mathrm{O}
$$

However, the chemical composition of the hydrated gypsum residue may be different from the natural gypsum that originated it, containing different levels of hemihydrates, anhydrites, and impurities. Also, the morphology of the dihydrate crystals resulting from hydration may be different from those composing natural gypsum due to the conditions in which the crystals were formed ${ }^{23,24}$.

\subsection{Application of parametric Rietveld refinements for in-situ monitoring of plaster hydration}

The mechanism of gypsum hydration has already been studied by several authors using various experimental techniques, such as thermogravimetry and particle size analysis, which can only be implemented ex-situ, thus requiring the halting of hydration reactions at different times to carry out the measurement, as well as the need of a sample for each time studied $^{25}$. In this way, in-situ monitoring of hydration becomes an exciting approach to evaluate the behavior of the material at the same time as the measurements are performed. One of the techniques used to monitor the hydration mechanism is calorimetric analysis.

Lewry and Williamson ${ }^{18}$ followed the hydration of the gypsum through SEM images and verified that the first stage occurs by the formation of the dihydrate crystals from the hydration of the hemihydrate. Adrien et al. ${ }^{25}$ monitored the hydration of the hemihydrate by X-ray tomography. The authors observed the dissolution of the hemihydrate and the formation of a network of dihydrate needles and determined the degree of reaction from a quantitative analysis of the evolution of microstructure in three-dimensional images. Solberg and Hansen ${ }^{17}$ studied, by synchrotron X-ray powder diffraction (S-XRPD), the hydration of hemihydrate pastes with $0.50 \%$ by mass of dihydrate "seeds" and water amounts equal to $0.50,0.75$, $1.00,1.25$ and 1.50 . The newly prepared pastes were packed into glass capillaries, positioned horizontally in the apparatus, and held in rotation, and the sequential XRPD measurements were performed over time. The authors verified that the rate of dissolution of the hemihydrate is equal to the precipitation rate of the dihydrate and that the amount of water does not exert a significant influence on the rate of reaction. Christensen et al. ${ }^{26}$ performed in-situ sequential S-XRPD of hydration of an $\alpha$-hemihydrate and 
dehydration of a sample of dihydrate with $\alpha$-hemihydrate. The authors have observed various phase changes, with the appearance and disappearance of peaks, both in the formation of the dihydrate from the hemihydrate during hydration and the formation of hemihydrate from the dihydrate during dehydration. The authors used the Rietveld refinement method in some measures to identify the phases present, as well as for quantitative phase analysis (QPA).

In-situ XRPD is a particularly favorable technique for the development of physical models of materials' behavior since data regarding the material structure can be collected depending on the processing or environmental variable of interest. It is already known that studies of X-ray diffraction as a function of an external variable such as temperature, time, pressure or chemical environment can bring more information about the system than a single experiment and such applications are gaining importance and being diffused in the area of XRPD as new pieces of equipment enable the collection of high-quality data. The application of the Rietveld method individually and independently to each set of data from these studies is the traditional way of handling this data, where the input conditions for the analysis of a set of individual data are taken from the output of the previous set of data sequentially. If, for example, 100 diffraction patterns of polycrystals are collected at different temperatures, each one with a refinement of 20 parameters, 100 independent refinements will be used with 2,000 parameters in total. However, it is clear that these 2,000 parameters are not entirely independent ${ }^{27,28}$.

Although this approach is useful in many cases, problems with parameter stability can arise when the concentrations of phases of interest are low, either when they begin to form or at the end of their decomposition. At these times, the observed intensity is unlikely to be sufficient to support the refinement of parameters such as peak profile (as used to estimate crystallite size) and crystal structure (atomic displacement parameters, for example). Some of these stability problems can be overcome by providing limits on parameter values during refinement, but the selection of these limits is often subjective and based on the analyst's experience ${ }^{27}$.

The methodology proposed by Stinton and Evans ${ }^{28}$, called parametric Rietveld refinement, defines that any parameter - such as lattice parameters or occupations of crystallographic sites - can be described by a single general value or by a function that describes its evolution along data collection, which reduces the number of refined parameters and can be refined simultaneously from a large number of diffraction data. In this way, it offers several potential benefits over independent or sequential analysis, as it allows greater accuracy of refined parameters, offers the possibility of applying physically realistic models during data analysis, allows the refinement of "noncrystallographic" parameters, such as temperature or rate constants directly from diffraction data, and may help to avoid false minimums. Stinton and Evans ${ }^{28}$ performed diffraction measurements as a function of temperature for a sample of $\mathrm{WO}_{3}$ and determined the phase transition by sequential refinements and parametric Rietveld. It is observed that the parametric refinement produced better results than the sequential refinement for the phase fractions as a function of temperature.

Thus, it is advantageous to determine by parametric Rietveld refinement the mass fractions of the anhydrite, hemihydrate and dihydrate phases of the plasters in in-situ XRPD measurements collected during the hydration of the pastes, comparing commercial and recycled samples. The objective of this work is to evaluate the effect of the recycling process on the reactivity, microstructure, and physical properties of 2 commercial plasters available in the São Paulo (Brazil) market.

\section{Experimental}

For the microstructural study of the materials, we used quantitative phase analysis (QPA) from the application of the Rietveld method to X-ray powder diffraction (XRPD) data as well as scanning electron microscopy (SEM). For the macrostructural characterization, we concentrated on evaluating the physical and mechanical properties of powdered, paste, and hardened plasters. For this, density, bulk density, grain size distribution, specific surface area (BET), microporosity, paste consistency, and temperature kinetics of the samples were studied. Sequential and parametric Rietveld refinement using XRPD data as a function of time obtained from in-situ monitoring of hydration of commercial and recycled samples were also performed.

Two commercial plaster samples from different manufacturers, here called $\mathrm{CP} 1$ and $\mathrm{CP} 2$, were purchased in the São Paulo, Brazil construction market. The plasters were hydrated with water/gypsum ratio $(w / g)$ of $60 \mathrm{wt} \%$ according to the procedure described in the standard NBR $12128^{29}$ for fresh state tests as well as for the production of the residue, and the samples were named HCP1 and HCP2. We chose to use the same amount of water in all samples to standardize the $w / g$ ratio. For the production of the recycled samples, the hydrated plasters were submitted to a laboratory recycling process. Initially, the material was ground in a hammer mill, and then $1.5 \mathrm{~kg}$ of material was distributed in aluminum trays in layers of 1 to $1.5 \mathrm{~cm}$ thick and brought to the oven at an average temperature of $160^{\circ} \mathrm{C}$ until reaching a mass constancy; the samples were named RP1 and RP2. The recycled samples were again hydrated with $60 \%$ water (HRP1 and HRP2) to evaluate the microstructure and the physical and mechanical properties. The time required to stabilize the mass loss of the samples during calcination was $300 \mathrm{~min}$, and the mass losses were equal to $15 \%$. 


\section{$3.1 X$-ray powder diffraction (XRPD) and Rietveld refinement}

For the XRPD assays, small aliquots (approximately $10 \mathrm{~g}$ ) of all gypsum samples under commercial, recycled, hydrated, and recycled and hydrated conditions were handground in an agate mortar with a pestle to obtain a fine powder. $\mathrm{X}$-ray powder diffraction data (XRPD) were collected on an STOE $^{\circledR}$ equipment, model STADI-P, with monochromatic radiation filtered by a primary beam monochromator (curved $\mathrm{Ge}(111)$ crystal $)$ with $\lambda=1.54056 \AA\left(\mathrm{CuKa}_{1}\right)$ operating at $40 \mathrm{kV}$ and $40 \mathrm{~mA}$, in the transmission geometry, with the samples loaded between two foils of acetate-cellulose in a sample holder kept spinning during data acquisition, in order to increase the counting statistics ${ }^{30}$. The diffracted intensities were recorded by a linear detector, Mythen $1 \mathrm{~K}$, in the $2 \theta$ range from $10^{\circ}$ to $90^{\circ}$, with steps of $0.015^{\circ}$ and an integration time of $120 \mathrm{~s}$ at each $1.05^{\circ}$.

The qualitative analysis of the phases present in the samples was carried out using the following software: Crystallographica Search-Match (integrated to a PDF2 database, distributed by International Centre for Diffraction Data - ICDD $-{ }^{31}$ and QualX2 $2^{32}$, using an internal version of the Crystallography Open Database - COD - ${ }^{33}$ available at http://crystallography. net, in order to gather the necessary structural information. To carry out the refinements by the Rietveld method, we used the software TOPAS-Academic v. $5^{34}$.

\subsection{Density, bulk density and compactness}

The densities of the hemihydrate (commercial and recycled) plasters were determined according to NBR NM $23^{35}$, and the tests for bulk density determination were carried out according to NBR $12127^{36}$.

\subsection{Particle size distribution and specific surface area (BET)}

The particle size distribution was obtained using a HELOS/ $B R$ laser granulometer, equipped with a Sucell automatic wet dispersion unit. For the tests, $0.15 \mathrm{~g}$ of the plasters in hemihydrate form were mechanically dispersed in $50 \mathrm{~mL}$ of anhydrous ethyl alcohol to prevent the dissolution of small particles during measurement at $1,000 \mathrm{rpm}$ for $60 \mathrm{~s}$. A $120 \mathrm{~s}$ ultrasonic bath was applied to the solution before measurement in order to avoid particle agglomeration and sedimentation, as indicated by Hunger and Brouwers?

The specific surface area of the plasters was measured by the BET method ${ }^{38}$, which is based on a mathematical formula ${ }^{4}$, where is the specific amount of gas adsorbed at a given relative pressure, is the parameter exponentially related to the energy of the monolayer adsorption and is the specific capacity of the monolayer), which describes the adsorption of a particular gas on the particulate material, allowing the measurement of both the external and internal surface area if the material has open pores on its surface ${ }^{39,40}$.

$$
\frac{p / p^{\circ}}{n\left(1-p / p^{\circ}\right)}=\frac{1}{n_{m} C}+\frac{c-1}{n_{m} c}\left(p / p^{\circ}\right)
$$

The tests were performed on a Belsorp Max equipment (Bel Japan brand), based on $\mathrm{N}_{2}$ adsorption on the sample solid surface. Samples were pretreated at a temperature of $40{ }^{\circ} \mathrm{C}$ for 16 hours in a Belprep-vacII equipment (Bel Japan brand), under a vacuum of $10^{-2} \mathrm{kPa}$, necessary conditions to prevent dehydration of the gypsum ${ }^{41}$.

\subsection{Consistency - mini-slump}

The consistency of the gypsum pastes can be evaluated by the mini-slump test, which is fast and straightforward to perform. In this test, the flowability of gypsum paste caused by the action of its weight is measured. A conical trunk shape mold opened at the ends is formed with dimensions equal to $20 \mathrm{~mm}$ (upper diameter), $40 \mathrm{~mm}$ (bottom diameter), and 60 $\mathrm{mm}$ height, with the freshly prepared paste on a glass plate arranged on a sheet of millimeter paper for centering the mold. After $60 \mathrm{~s}$, the mold is slowly vertically withdrawn, and the spread material is measured with the aid of a pachymeter in its orthogonal diameters. The result is the average of the two diameters in centimeters ${ }^{42,43}$.

\subsection{Temperature kinetics}

The plaster temperature kinetics can be studied from calorimetry tests. In order to perform measurements of temperature as a function of time, a pseudo-adiabatic calorimeter similar to those used by Carvalho et al. ${ }^{44}$, was constructed, consisting of a closed styrofoam container for insulation of the medium system filled with styrofoam spheres for increased heat retention efficiency, a styrofoam cup for plaster paste placement, a type K (Cromel-Alumel) thermocouple coupled to a digital thermometer with $0.1^{\circ} \mathrm{C}$ accuracy and a stopwatch. The gypsum paste was prepared according to standard NBR $12128^{29}$ already inside the styrofoam cup and immediately inserted into the calorimeter in the middle of styrofoam spheres. The thermocouple used for temperature measurement was then inserted into the paste, and the assembly closed to avoid exposure to the external medium. The temperature values, in ${ }^{\circ} \mathrm{C}$, were taken every $15 \mathrm{~s}$. The total mass of the pastes was kept constant in 100 $\mathrm{g}$, composed of $62.5 \mathrm{~g}$ gypsum and $37.5 \mathrm{~g}$ water at room temperature (ratio $\mathrm{w} / \mathrm{g}=60 \%$ ).

\subsection{In-situ monitoring of plaster hydration by $X R P D$}

In-situ monitoring of the hydration of the plasters was carried out using XRPD data to verify the reactivity and evaluate the hydration of the plasters over time, from the first instants after mixing the material with water until the temperature was stabilized in the temperature kinetics assays. Gypsum pastes were prepared with commercial samples (CP1 and CP2), with the $w / g$ ratio of $60 \%$. The gypsum 
masses used were approximately $0.3 \mathrm{~g}$ since the amount of sample used in the assay is reduced. Immediately after the preparation, the slides were deposited on the sample holders. All the measurements started after 3 minutes counted from the moment the plaster was put in contact with the water. The diffracted intensities were collected from $10^{\circ}$ to $28.9^{\circ}$, with different integration times for each sample, as shown in Table 1. It was chosen to carry out measurements in the fixed range in the initial region of the diffractograms since it is known that the peaks with the strongest intensities of bassanite and gypsum are found in this region. The selection of the acquisition time was made in order to guarantee adequate counting statistics, and for the recycled samples, a shorter time was used, when possible, due to the high reactivity of these samples already known by the temperature kinetic tests.

Table 1. Integration time used for in-situ XRPD measurements.

\begin{tabular}{lcc}
\hline Sample & Integration time (s) & $\begin{array}{c}\text { Measurement duration } \\
\text { (min) }\end{array}$ \\
\hline CP1 & 300 & 45 \\
RP1 & 120 & 30 \\
CP2 & 300 & 40 \\
RP2 & 300 & 30 \\
\hline
\end{tabular}

\subsection{Scanning electron microscopy (SEM)}

The scanning electron microscopy images were acquired on a scanning electron microscope (ESEM), model Quanta 650 FEG, from $F E I^{\circledR}$. The secondary electron images were obtained with current applied to the $10 \mathrm{kV}$ electron source and $10 \mathrm{~mm}$ working distance. The backscattered electron images, as well as the chemical analyses by EDS, were obtained with a current of $20 \mathrm{kV}$ and a working distance of $13.5 \mathrm{~mm}$. Samples were prepared from the hydration of the commercial and recycled plasters in a ceramic vessel, using a $60 \% \mathrm{w} / \mathrm{g}$ ratio. The slides were allowed to stand on the laboratory bench until complete drying (at least 24 hours). The hardened pastes were fractured with the aid of a spatula to form small fragments since the major purpose of this test was to verify the morphology of the pastes obtained with both the commercial and recycled plaster and not the evaluation of the hemihydrates. The samples of hydrated gypsum fragments were fixed in an electron microscopy support with double-sided carbon tape and received fine platinum coverage (Bal-tec coater, model MED-020).

\section{Results and Discussion}

\subsection{X-ray powder diffraction (XRPD) and Rietveld refinement}

Table 2 shows the ICSD ${ }^{1}$ and COD files of each one of the identified phases, as well as their crystallographic information framework (CIF) files. The dihydrate $\left(\mathrm{CaSO}_{4} \cdot 2 \mathrm{H}_{2} \mathrm{O}\right)$ is referred to as gypsum and the hemihydrate $\left(\mathrm{CaSO}_{4} \cdot 0.5 \mathrm{H}_{2} \mathrm{O}\right)$ as bassanite in the names of the phases present in the crystallographic files.

Quantitative phase analyses (QPA) were extracted from the refinements, and the results, including errors (weighted Durbin-Watson statistics $-\mathrm{d}-\mathrm{DW}-{ }^{45}$ is quite low and indicate the deviations are underestimated. It should be noticed there is no proper physical model to correct the standard deviations in the Rietveld method that can make them representative of the repetition of the experiment) appearing in parentheses, are illustrated in the Rietveld plots shown Figure 1 and Figure 2.

In all refinements the unit cell parameters, the background radiation (using an 8-term Chebyschev polynomial), the zero error of the diffractometer, the absorption correction of both the sample and that related to the use of the acetate-cellulose foils and the scale factor for all the phases present in the samples were refined, and it was observed that some phases presented isotropic microstrain and preferred orientation of the crystallites, being this last factor modeled with a 4-term spherical harmonics function. The bassanite phase was also corrected with an anisotropic peak broadening based on the model of Le Bail and Jouanneaux ${ }^{46}$. The fractional coordinates of all atoms were kept fixed except for the bassanite phase of the recycled samples - CP1, CP2, and RP2 - since for these materials, we used the COD 9012211 file, which showed better adjustment when this procedure was adopted.

Commercial plaster samples CP1 and CP2 presented low amounts of impurities such as anhydrite and dolomite. In both cases, the anhydrite content was reduced after hydration of the material (samples HCP1 and HCP2). The recycling process was efficient since the composition of the recycled samples (RP1 and RP2) is very similar to the commercial samples, as well as recycled and hydrated samples (HRP1 and HRP2), which have almost identical compositions of hydrated commercial samples.

Table 3 presents the statistical parameters $R_{w p}, \chi^{2}, R_{\text {Bragg }}{ }^{47}$ of the Rietveld refinement of the main phases present in each sample (bassanite for the plasters in the form of hemihydrate and gypsum for the plasters in the form of dihydrate), as well as the refined unit cell parameters.

\subsection{Bulk density, density and compactness}

The average results of three determinations, as well as the compactness - the ratio between bulk density and density - are shown in Figure 3.

As can be observed, plasters present a density average of $2,600 \mathrm{~kg} \cdot \mathrm{m}^{-3}$, a value consistent with the specific mass of the hemihydrate $2\left(2,630 \mathrm{~kg} \cdot \mathrm{m}^{-3}\right)$. On the other hand, the bulk density reduced considerably for all plasters after the recycling process: $27 \%$ for plaster 1 and $36 \%$ for plaster 2 , which was reflected in the loss of compactness for all samples. With this, it is assumed that the recycled plaster becomes more porous than the commercial plaster that gave rise to it.

\footnotetext{
${ }^{1}$ ICSD files - Inorganic Crystal Structure Database - accessed via BDEC - Crystal Structures Bases (http://bdec.dotlib.com.br).

${ }^{2}$ http://www.inchem.org/documents/icsc/icsc/eics1217.htm
} 
Table 2. Information on the data sheets used in Rietveld refinements obtained from COD and ICSD.

\begin{tabular}{|c|c|c|c|c|}
\hline Phase name (chemical formula) & Space group/ Crystal system & Unit cell parameters & COD file & ICSD file \\
\hline \multirow{5}{*}{$\begin{array}{l}\text { Gypsum } \\
\left(\mathrm{CaSO}_{4} \cdot 2 \mathrm{H}_{2} \mathrm{O}\right)\end{array}$} & \multirow{5}{*}{$\begin{array}{c}C 2 / c / \\
\text { Monoclinic }\end{array}$} & $\mathrm{a}=6.277(2) \AA$ & \multirow{5}{*}{$9013164^{56}$} & \multirow{5}{*}{-} \\
\hline & & $\mathrm{b}=15.181(6) \AA$ & & \\
\hline & & $\mathrm{c}=5.672(2) \AA$ & & \\
\hline & & $\beta=114.11(2)^{\circ}$ & & \\
\hline & & $\mathrm{V}=493.36(35) \AA^{3}$ & & \\
\hline \multirow{10}{*}{$\begin{array}{l}\text { Bassanite } \\
\left(\mathrm{CaSO}_{4} \cdot 2 \mathrm{H}_{2} \mathrm{O}\right)\end{array}$} & \multirow{5}{*}{$\begin{array}{c}C 2 / \\
\text { Monoclinic }\end{array}$} & $\mathrm{a}=17.5180(8) \AA$ & \multirow{5}{*}{$2105042^{57}$} & \multirow{5}{*}{-} \\
\hline & & $\mathrm{b}=6.92910(1) \AA$ & & \\
\hline & & $\mathrm{c}=12.0344(2) \AA$ & & \\
\hline & & $\beta=133.655(1)^{\circ}$ & & \\
\hline & & $V=1056.88(4) \AA^{3}$ & & \\
\hline & \multirow{5}{*}{$\begin{array}{c}I 2 / \\
\text { Monoclinic }\end{array}$} & $\mathrm{a}=12.0317(4) \AA$ & \multirow{5}{*}{$9012209 * 58$} & \multirow{5}{*}{-} \\
\hline & & $\mathrm{b}=6.9269(2) \AA$ & & \\
\hline & & $\mathrm{c}=12.6712(3) \AA$ & & \\
\hline & & $\beta=90.27(1)^{\circ}$ & & \\
\hline & & $V=1056.04 \AA^{3}$ & & \\
\hline \multirow{5}{*}{$\begin{array}{l}\text { Bassanite } \\
\left(\mathrm{CaSO}_{4} \cdot 0.583 \mathrm{H}_{2} \mathrm{O}\right)\end{array}$} & \multirow{5}{*}{$\begin{array}{c}I 2 / \\
\text { Monoclinic }\end{array}$} & $\mathrm{a}=11.9845(4) \AA$ & \multirow{5}{*}{$9012211 * 58$} & \multirow{5}{*}{-} \\
\hline & & $\mathrm{b}=6.9292(2) \AA$ & & \\
\hline & & $\mathrm{c}=12.7505(3) \AA$ & & \\
\hline & & $\beta=90.0^{\circ}$ & & \\
\hline & & $\mathrm{V}=1058.84 \AA^{3}$ & & \\
\hline \multirow{4}{*}{$\begin{array}{l}\text { Anhydrite } \\
\left(\mathrm{CaSO}_{4}\right)\end{array}$} & \multirow{4}{*}{$\begin{array}{c}\text { Bbmm / } \\
\text { Orthorhombic }\end{array}$} & $\mathrm{a}=6.23 \AA$ & & \multirow{4}{*}{$28546^{* 55}$} \\
\hline & & $\mathrm{b}=6.98 \AA$ & & \\
\hline & & $c=6.97 \AA$ & - & \\
\hline & & $\mathrm{V}=303.09 \AA^{3}$ & & \\
\hline \multirow{3}{*}{$\begin{array}{l}\text { Dolomite } \\
\left(\mathrm{MgCaC}_{2} \mathrm{O}_{6}\right)\end{array}$} & \multirow{3}{*}{$\begin{array}{c}R \overline{3} c / \\
\text { Trigonal }\end{array}$} & $\mathrm{a}=\mathrm{b}=4.8072(1) \AA$ & \multirow{3}{*}{$9003508^{60}$} & \multirow{3}{*}{-} \\
\hline & & $\mathrm{c}=16.0048(4) \AA$ & & \\
\hline & & $\mathrm{V}=320.31(1) \AA^{3}$ & & \\
\hline \multirow{3}{*}{$\begin{array}{l}\text { Calcite } \\
\left(\mathrm{CaCO}_{3}\right)\end{array}$} & \multirow{3}{*}{$\begin{array}{c}R \overline{3} c / \\
\text { Trigonal }\end{array}$} & $\mathrm{a}=\mathrm{b}=4.9742(1) \AA$ & \multirow{3}{*}{$9015460^{61}$} & \multirow{3}{*}{-} \\
\hline & & $\mathrm{c}=17.4676(5) \AA$ & & \\
\hline & & $\mathrm{V}=374.29(2) \AA^{3}$ & & \\
\hline \multirow{3}{*}{$\begin{array}{l}\text { Quartz } \\
\left(\mathrm{SiO}_{2}\right)\end{array}$} & \multirow{3}{*}{$\begin{array}{l}P 3_{1} 21 / \\
\text { Trigonal }\end{array}$} & $\mathrm{a}=\mathrm{b}=4.9134 \AA$ & & \\
\hline & & $\mathrm{c}=5.4052 \AA$ & - & $174 * 62$ \\
\hline & & $\mathrm{V}=113.01 \AA^{3}$ & & \\
\hline & & $\mathrm{a}=4.7536(1) \AA$ & & \\
\hline Olivine & Pbnm / & $\mathrm{b}=10.2066(2) \AA$ & 900639863 & \\
\hline$\left(\mathrm{Mg}_{2} \mathrm{O}_{4} \mathrm{Si}\right)$ & Orthorhombic & $\mathrm{c}=5.9845(2) \AA$ & 9000590 & - \\
\hline & & $\mathrm{V}=290.36(3) \AA^{3}$ & & \\
\hline
\end{tabular}

\subsection{Particle size distribution and specific surface area (BET)}

The particle size distribution of the hemihydrates (commercial and recycled) plasters are shown in Figure 4. In order to make a suitable comparison between different samples, Table 4 shows the mean diameter values $\left(D_{50}\right)$, the amplitude measurement of the distribution defined by the difference between the 10th and the 90th percentile values
$\left(D_{90}-D_{10}\right)$ and the theoretical volumetric surface area (VSA, in $\mathrm{m}^{2} \cdot \mathrm{cm}^{-3}$ ), which is calculated from the product between the theoretical specific surface area and the particle density ${ }^{48}$, since these values are less subject to random variations ${ }^{49}$.

The granulometric distributions show that, for all plasters, the grinding process was efficient, since all the samples had similar behaviors compared to the values of accumulated percentage (red curves - right y-axis of the graphs), which 

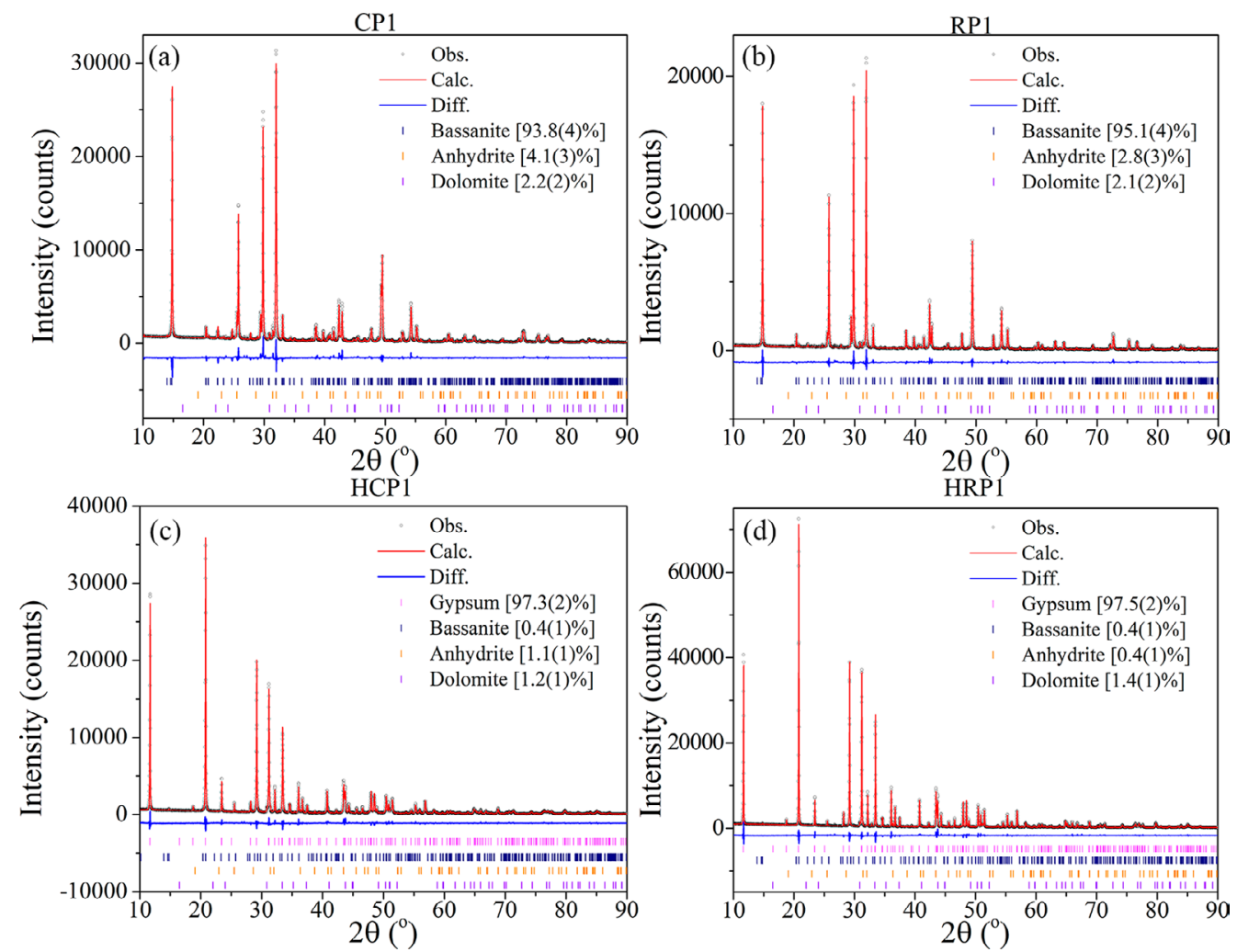

Figure 1. Rietveld plot and quantitative phase analysis of samples (a) CP1, (b) RP1, (c) HCP1, and (d) HRP1. The open circles represent the observed data, the red line represents the calculated values, and the blue line is the difference between the calculated and observed data. Vertical bars represent the peak positions of each phase.
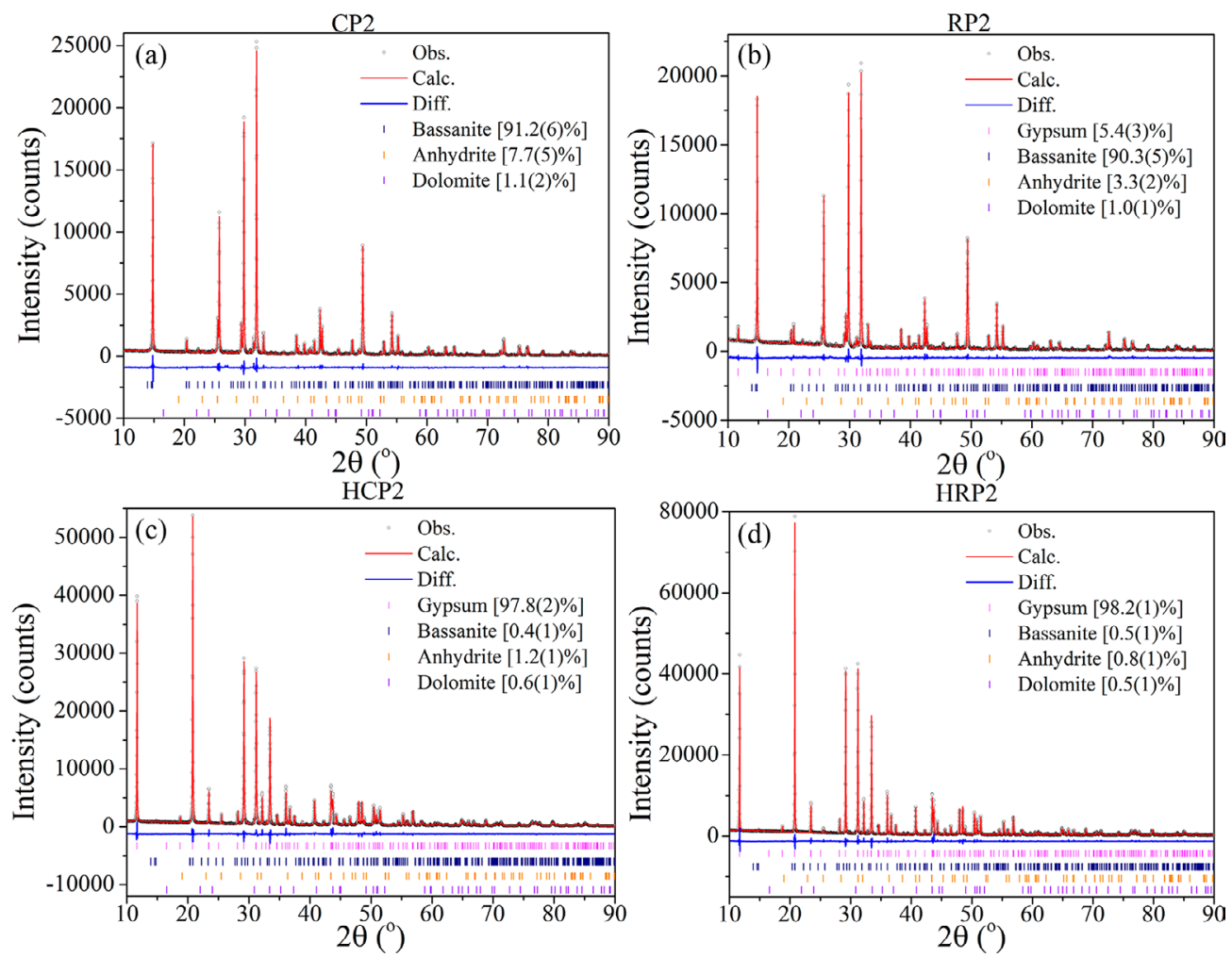

Figure 2. Rietveld plot and quantitative phase analysis of samples (a) CP2, (b) RP2, (c) HCP2, and (d) HRP2. The open circles represent the observed data, the red line represents the calculated values, and the blue line is the difference between the calculated and observed data. Vertical bars represent the peak positions of each phase. 
Table 3. $R_{w p}, \chi^{2}, R_{\text {Bragg }}$, and unit cell parameters of main phases after refinement.

\begin{tabular}{|c|c|c|c|c|c|}
\hline Sample & Phase & $\boldsymbol{R}_{w p}$ & $\chi^{2}$ & $\boldsymbol{R}_{\text {Bragg }}$ & $\begin{array}{l}\text { Unit cell parameters } \\
\text { after refinement }\end{array}$ \\
\hline \multirow{4}{*}{$\mathrm{CP} 1$} & & \multirow{4}{*}{$8.176 \%$} & \multirow{4}{*}{1.924} & \multirow{4}{*}{$3.923 \%$} & $\mathrm{a}=12.0066(5) \AA$ \\
\hline & Bassanite & & & & $\mathrm{b}=6.9183(3) \AA$ \\
\hline & 9012209 & & & & $c=12.6486(4) \AA$ \\
\hline & & & & & $\beta=90.224(2)^{\circ}$ \\
\hline \multirow{4}{*}{ RP1 } & & \multirow{4}{*}{$7.982 \%$} & \multirow{4}{*}{1.413} & \multirow{4}{*}{$1.484 \%$} & $\mathrm{a}=17.481(2) \AA$ \\
\hline & Bassanite & & & & $\mathrm{b}=6.9237(5) \AA$ \\
\hline & 9012211 & & & & $\mathrm{c}=11.9908(6) \AA$ \\
\hline & & & & & $\beta=133.395(3)^{\circ}$ \\
\hline \multirow{4}{*}{ HCP1 } & & \multirow{4}{*}{$7.052 \%$} & \multirow{4}{*}{1.597} & \multirow{4}{*}{$1.824 \%$} & $\mathrm{a}=6.2718(4) \AA$ \\
\hline & Gypsum & & & & $\mathrm{b}=15.1812(7) \AA$ \\
\hline & 9013164 & & & & $c=5.6667(4) \AA$ \\
\hline & & & & & $\beta=114.093(2)^{\circ}$ \\
\hline \multirow{4}{*}{ HRP1 } & & \multirow{4}{*}{$7.236 \%$} & \multirow{4}{*}{2.028} & \multirow{4}{*}{$2.125 \%$} & $\mathrm{a}=6.2727(2) \AA$ \\
\hline & Gypsum & & & & $b=15.1787(4) \AA$ \\
\hline & 9013164 & & & & $\mathrm{c}=5.6671(1) \AA$ \\
\hline & & & & & $\beta=114.094(1)^{\circ}$ \\
\hline \multirow{4}{*}{$\mathrm{CP} 2$} & & \multirow{4}{*}{$7.112 \%$} & \multirow{4}{*}{1.370} & \multirow{4}{*}{$1.252 \%$} & $\mathrm{a}=11.9962(6) \AA$ \\
\hline & Bassanite & & & & $\mathrm{b}=6.9155(2) \AA$ \\
\hline & 9012211 & & & & $\mathrm{c}=12.7070(3) \AA$ \\
\hline & & & & & $\beta=90.023(4)^{\circ}$ \\
\hline \multirow{4}{*}{$\mathrm{RP} 2$} & & \multirow{4}{*}{$6.954 \%$} & \multirow{4}{*}{1.462} & \multirow{4}{*}{$1.756 \%$} & $\mathrm{a}=11.9877(4) \AA$ \\
\hline & Bassanite & & & & $\mathrm{b}=6.9213(2) \AA$ \\
\hline & 9012211 & & & & $\mathrm{c}=12.7091(3) \AA$ \\
\hline & & & & & $\beta=90.053(2)^{\circ}$ \\
\hline \multirow{4}{*}{$\mathrm{HCP} 2$} & & \multirow{4}{*}{$7.079 \%$} & \multirow{4}{*}{1.951} & \multirow{4}{*}{$1.886 \%$} & $\mathrm{a}=6.2714(3) \AA$ \\
\hline & Gypsum & & & & $\mathrm{b}=15.1843(6) \AA$ \\
\hline & 9013164 & & & & $c=5.6686(2) \AA$ \\
\hline & & & & & $\beta=114.081(1)^{\circ}$ \\
\hline \multirow{4}{*}{ HRP2 } & & \multirow{4}{*}{$6.941 \%$} & & & $\mathrm{a}=6.2717(1) \AA$ \\
\hline & Gypsum & & 2112 & $2056 \%$ & $\mathrm{~b}=15.1849(4) \AA$ \\
\hline & 9013164 & & 2.112 & 2.05070 & $\mathrm{c}=5.6690(1) \AA$ \\
\hline & & & & & $\beta=114.0792(8)^{\circ}$ \\
\hline
\end{tabular}

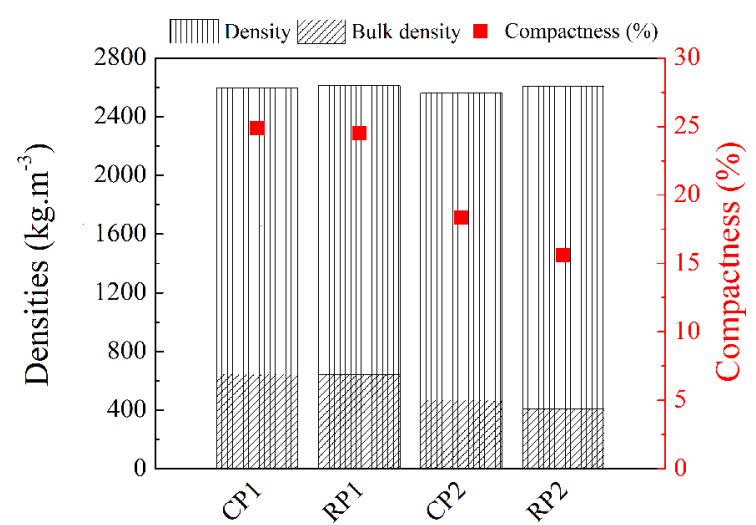

Figure 3. Bulk density (diagonal stripes), density (vertical stripes), and compactness (red squares) of plasters. can be observed by the displacement of the accumulated percentage curve to the left or the reduction in their average particle sizes $\left(D_{50}\right)$. This fact can also be verified by the reduction of the values of distribution amplitude after the recycling since the difference between the particle sizes is smaller. Besides, the volumetric surface area increased for all plasters after recycling: $10.6 \%$ for plaster 1 and $45 \%$ for plaster 2, indicating an increase in the fineness of these materials. The results of the specific surface area are found in Table 5.

In general, a tendency of increase in the fineness of the plasters is observed after the recycling process, which was already expected by the granulometric distribution 

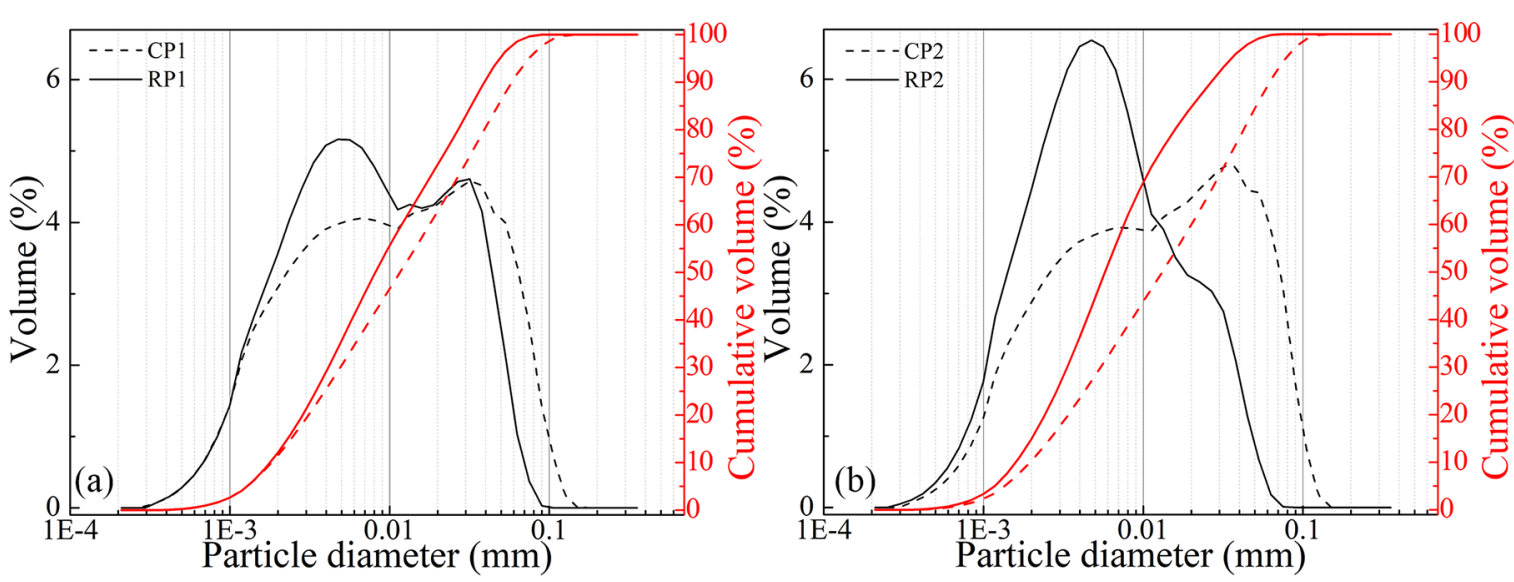

Figure 4. Particle size distribution of samples (a) CP1 and RP1 and (b) CP2 and RP2.

Table 4. Values of average diameter $\left(D_{50}\right)$, amplitude of distribution $\left(D_{90}-D_{10}\right)$, and theoretical volumetric surface area (VSA) of commercial and recycled plasters.

\begin{tabular}{cccccc}
\hline Sample & $\boldsymbol{D}_{\mathbf{5 0}}(\boldsymbol{\mu m})$ & $\boldsymbol{D}_{\mathbf{1 0}}(\boldsymbol{\mu m})$ & $\boldsymbol{D}_{\mathbf{9 0}}(\boldsymbol{\mu m})$ & $\boldsymbol{D}_{\mathbf{9 0}}-\boldsymbol{D}_{\mathbf{1 0}}$ & $\mathbf{V S A}\left(\mathbf{m}^{\mathbf{2}} \cdot \mathbf{c m}^{-\mathbf{3}}\right)$ \\
\hline CP1 & 11.64 & 1.82 & 58.66 & 56.84 & 1.22 \\
$\mathrm{RP1}$ & 8.15 & 1.78 & 39.36 & 37.58 & 1.35 \\
CP1 & 13.20 & 1.95 & 62.19 & 60.24 & 1.13 \\
RP1 & 5.76 & 1.59 & 26.72 & 25.13 & 1.64 \\
\hline
\end{tabular}

Table 5. Specific surface area (BET) of hemihydrate samples.

\begin{tabular}{ll}
\hline Sample & BET $\left(\mathbf{m}^{\mathbf{2}} \cdot \mathbf{g}^{-1}\right)$ \\
\hline CP1 & 2.66 \\
RP1 & 5.98 \\
CP2 & 2.45 \\
RP2 & 3.46 \\
\hline
\end{tabular}

results. This increase in the specific surface area may be related to the microporosity present in the material since the micropores have a high internal surface area and, if present in large quantities, contribute significantly to the increase of the specific surface area ${ }^{50}$. This fact corroborates the discussion about the reduction of the apparent mass and the compactness due to the increase of the porosity of the material. From the BET data, the pore volume distribution $\left(\Sigma V_{p}\right)$ was estimated as a function of its diameter based on the methodology proposed by Lippens and Boer ${ }^{51}$, and the graphs are shown in Figure 5.

It is observed that after recycling, the microporosity of the plaster increased, and the effect was more significant for the CP1 sample, justifying the high increase in the values of specific surface area verified by the BET test.

\subsection{Consistency - mini-slump}

All commercial samples showed fluidity, as can be seen in Figure 6, and the results are presented in Table 6.

The commercial plaster pastes showed similar consistency. The values are consistent with those presented by Munhoz ${ }^{42}$ for gypsum pastes prepared with $w / g$ ratio of 0.70 and by Pinheiro $^{11}$ for gypsum pastes with $80 \%$ of water. However, during the preparation of the recycled gypsum pastes, the material already showed practically instant viscosity increase, and it was not possible to mold the trunk-cone, as observed in gypsum paste RP1 of Figure 7. All the water appeared to be absorbed by the material before mixing, which may be related to the increase in porosity previously reported.

These results are consistent with the study of Ye et al. ${ }^{52}$, who found that slides prepared with thinner plasters required a higher amount of water to achieve normal consistency than pastes prepared with the coarser material. Rossetto et al..$^{53}$ also failed to determine the consistency of recycled plaster pastes, calcined for different periods at $150{ }^{\circ} \mathrm{C}$, prepared with $w / g$ ratios equal to 0.70 and 0.80 .

\subsection{Temperature kinetics}

We tracked how temperature varied with time, and the results are shown in Figure 8. Measurements of commercial plaster pastes began after 5 minutes of plaster contact with water and recycled plaster after 2 minutes. Even so, it was not possible to measure the induction step of the recycled material, again indicating that the reaction of the recycled plaster with water is instantaneous.

In Table 7, we summarize the values of the induction period, defined by Ridge ${ }^{54}$ as the time required for the rate of increase of temperature to exceed $0.1^{\circ} \mathrm{C} \cdot \mathrm{min}^{-1}$, the maximum temperature reached by the material $\left(T_{\max }\right)$ and time to reach the maximum temperature. 

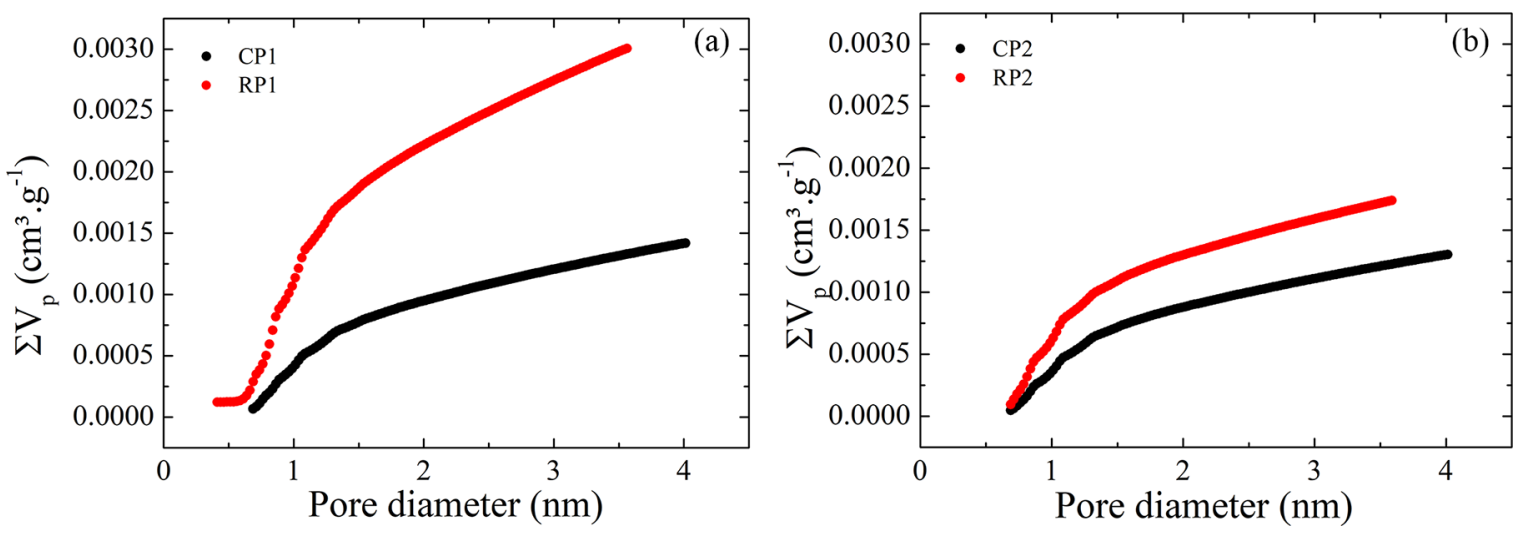

Figure 5. Pore volume distribution as a function of the diameter for the (a) CP1 and RP1 and (b) CP2 and RP2.
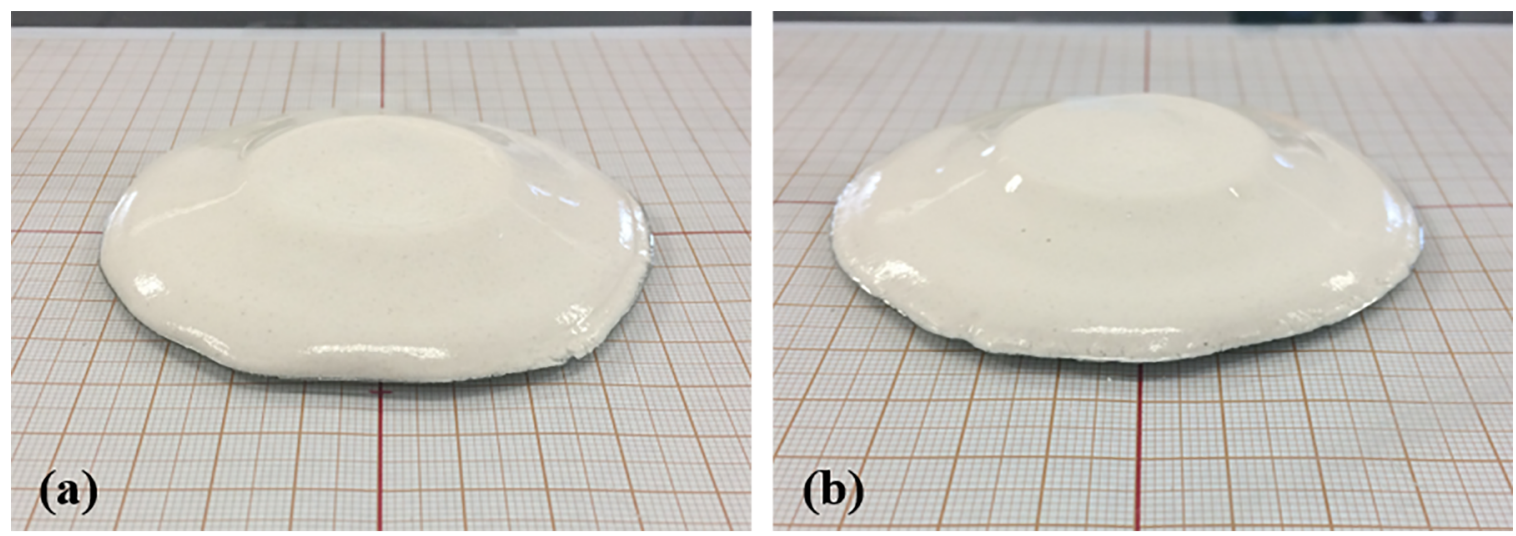

Figure 6. Consistency test of commercial plasters by mini-slump:

(a) CP1 and (b) CP2.

Table 6. Mini-slump consistency results of commercial samples.

\begin{tabular}{ll}
\hline Sample & Consistency $(\mathbf{c m})$ \\
\hline CP1 & 8.70 \\
CP2 & 9.07 \\
\hline
\end{tabular}

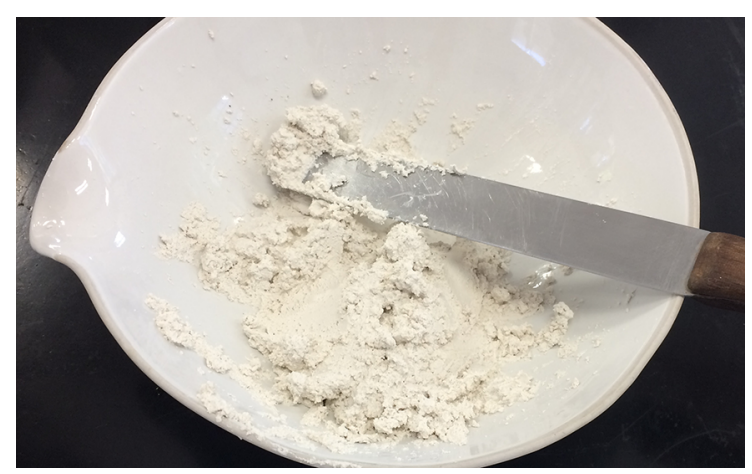

Figure 7. Freshly prepared RP1 paste.

The plasters were very similar in temperature kinetics for both commercial and recycled samples. It was not possible to determine the induction time of the recycled samples since the temperature increase rate of these plasters at the beginning of the test (between 2 and 3 minutes) had already exceeded $0.1^{\circ} \mathrm{C} \cdot \mathrm{min}^{-1}$. It is also noted that the recycled samples had almost no change in the maximum hydration temperature relative to their respective commercial samples.

The behavior of the recycled plasters compared to the commercial plasters was quite similar for all samples, with increased reactivity of the material revealed by the significant reduction of the time to reach the maximum temperature: 2.5 times for sample 1 and 3 times for sample 2, which can also be observed by moving the hydration curves to the left.

In the search to explain what caused the phenomenon of rapid reaction and water absorption of the recycled samples, the kinetic activity, defined by Lewry and Williamson ${ }^{15}$ as the maximum rate of increase of temperature as a function of time, i.e., the maximum point of the derivative, was related to the compactness and specific surface area (Figure 9).

In Figure 9, it is observed that the kinetic activity is inversely proportional to the compactness and directly proportional to the specific surface area of the material. It means the larger the contact area of the plaster with water, the more reactive it is. This observation is in agreement with the studies of John and Cincotto ${ }^{10}$ and Ye et al. ${ }^{52}$, who stated the larger the specific surface area, the larger the reaction area, the faster the dissolution, the higher the reaction rate and the shorter the induction period of the material. Adrien et al. ${ }^{25}$ 

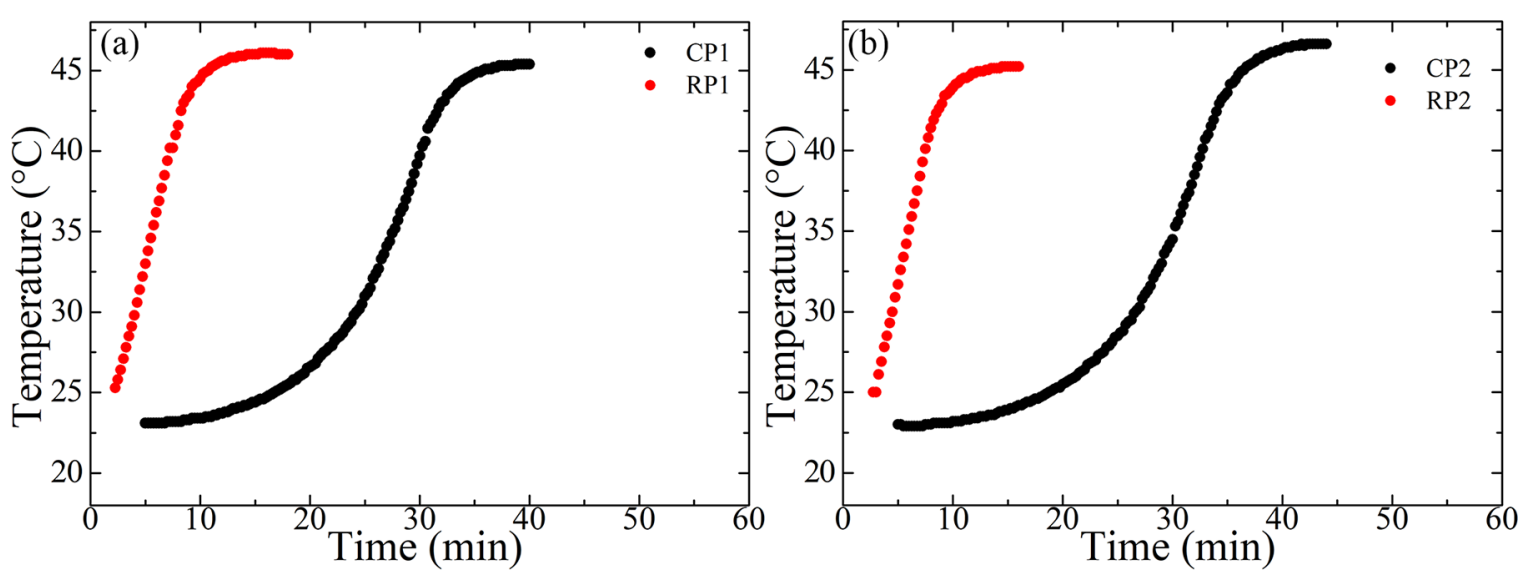

Figure 8. Temperature versus time of (a) CP1 and RP1 pastes and (b) CP2 and RP2 pastes.

Table 7. Estimation of the induction period, the maximum temperature reached in the temperature kinetics test, and the elapsed time to reach the maximum temperature.

\begin{tabular}{lccc}
\hline Sample & $\begin{array}{c}\text { Induction } \\
\text { period } \\
\text { (min:sec) }\end{array}$ & $\begin{array}{c}\mathbf{T}_{\max } \\
\left({ }^{\circ} \mathbf{C}\right)\end{array}$ & $\begin{array}{c}\text { Time to reach the } \\
\text { maximum temperature } \\
\mathbf{T}_{\text {max }} \text { (min:sec) }\end{array}$ \\
\hline CP1 & $10: 15$ & 45.4 & $38: 45$ \\
RP1 & $*$ & 46.0 & $15: 30$ \\
CP1 & $9: 45$ & 46.6 & $42: 15$ \\
RP1 & $*$ & 45.2 & $14: 30$ \\
\hline
\end{tabular}

* could not be determined

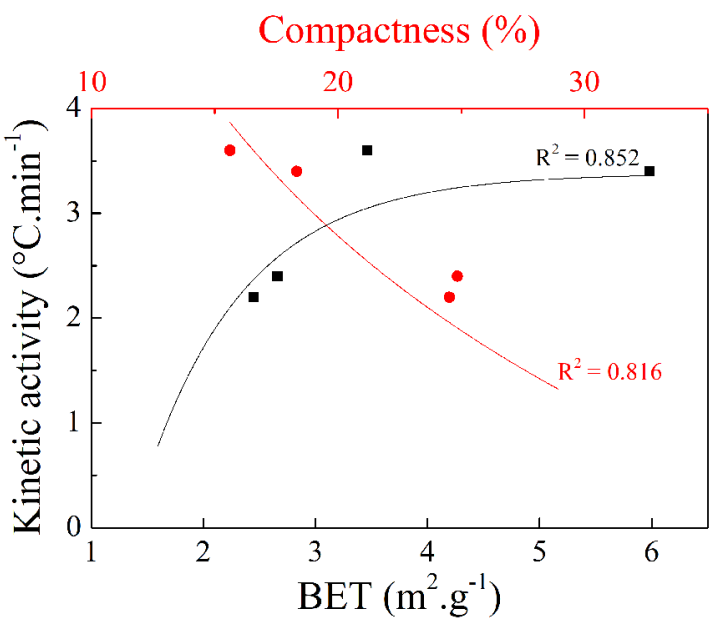

Figure 9. Relationship between kinetic activity, compactness, and specific surface area (BET) of plasters

verified by X-ray tomography analysis that the size of the hemihydrate particles influences the temperature kinetics and the microstructure of the cured material.

\subsection{In-situ monitoring of plaster hydration by XRPD}

Figure 10 and Figure 11 show the diffraction patterns as a function of time obtained for in-situ measurements of hydration of gypsum pastes, highlighting some main peaks of the anhydrite (A), bassanite (B) and gypsum (G), where it is possible to observe significant differences in the behavior of the commercial and recycled samples. In the latter, the first diffraction pattern already presents intense gypsum peaks $\left(11.7^{\circ}, 20.7^{\circ}\right.$, and $\left.23.4^{\circ}\right)$ while in the commercial samples, the gypsum phase only begins to appear in the measurements carried out at $600 \mathrm{~s}$ or $900 \mathrm{~s}$ depending on the material. It is worth noting that as the peaks of the bassanite phase become less intense, the peaks of the gypsum phase become more intense, demonstrating the formation of this compound takes place from the reaction of bassanite with water.

Although for plaster 2 the integration time of the measurements was equal to $300 \mathrm{~s}$ for both the commercial and recycled materials, it is seen that the data quality of the recycled samples is lower than those of the commercial samples, since the intensity of the peaks showed significant variation (from 1,500 counts in the CP1 sample to 300 counts in the RP1 sample). As the main objective was to study the effect of hydration in the first instants after mixing gypsum with water, it was decided to maintain the measurements with these acquisition times to better follow the alteration between the bassanite and gypsum phases, even though they compromised the quality of the data collected.

With XRPD data collected during the hydration of the samples, the sequential Rietveld refinement was carried out to determine the mass fractions of the calcium sulfate (anhydrite, bassanite, and gypsum) compounds. The CIF files of each phase used in the sequential refinements are the same as those used in the refinements of the dry materials. In order to carry out the sequential refinement, the refined values obtained in the refinement of the previous measurement are used as input data of the subsequent instant. For example, the input data of the refinement performed at the instant of $600 \mathrm{~s}$ are the output data of the refinement performed at the instant of $300 \mathrm{~s}$ and so on. For each sample, 11 unit cell parameters $(a, b, c$ and $\beta$ of the gypsum and bassanite phases and $a, b$ and $c$ of the anhydrite phase) were refined, totaling 99 refined parameters in the CP1 sample, 165 refined parameters in the RP1 sample, 88 refined parameters in the sample $\mathrm{CP} 2$ and 66 refined parameters in sample RP2. The results of the mass fractions as a function of the hydration time of the samples resulting from the sequential refinements are shown in Figure 12 and Figure 13. 

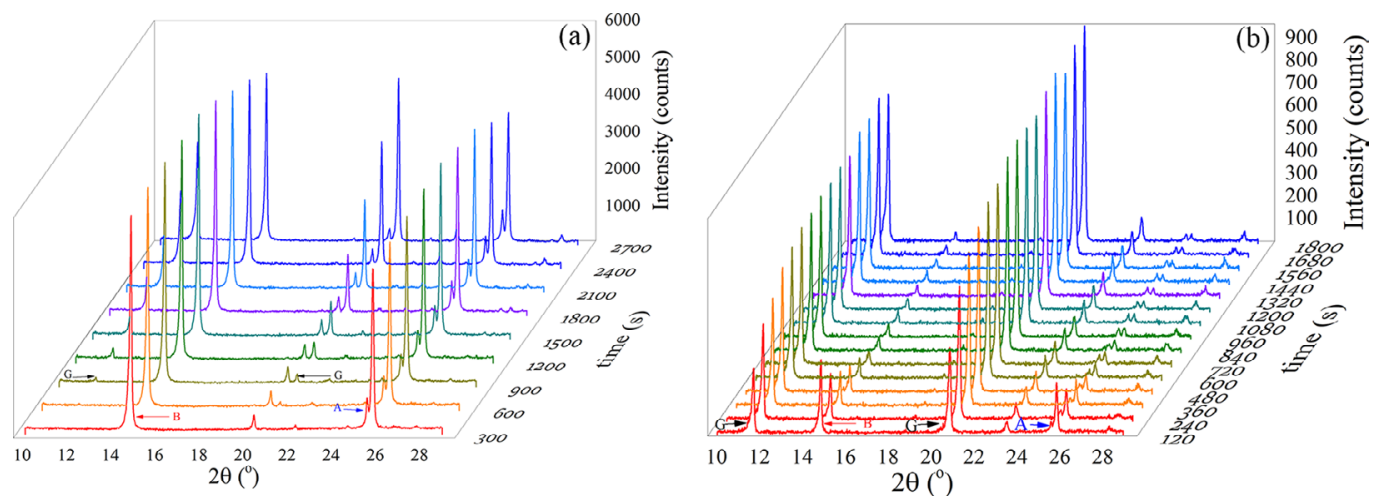

Figure 10. In-situ XRPD patterns of the hydration of samples (a) CP1 and (b) RP1. We highlight the main peaks of the anhydrite (A) bassanite $(B)$ and gypsum $(G)$ phases.

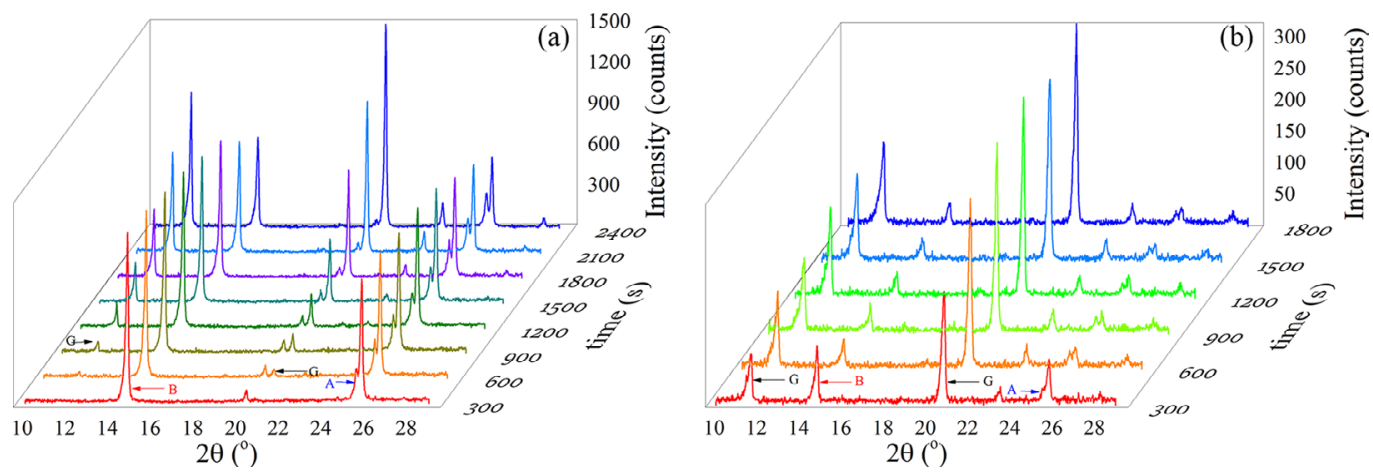

Figure 11. In-situ XRPD patterns of the hydration of samples (a) CP2 and (b) RP2. We highlight the main peaks of the anhydrite (A) bassanite (B) and gypsum $(\mathrm{G})$ phases.
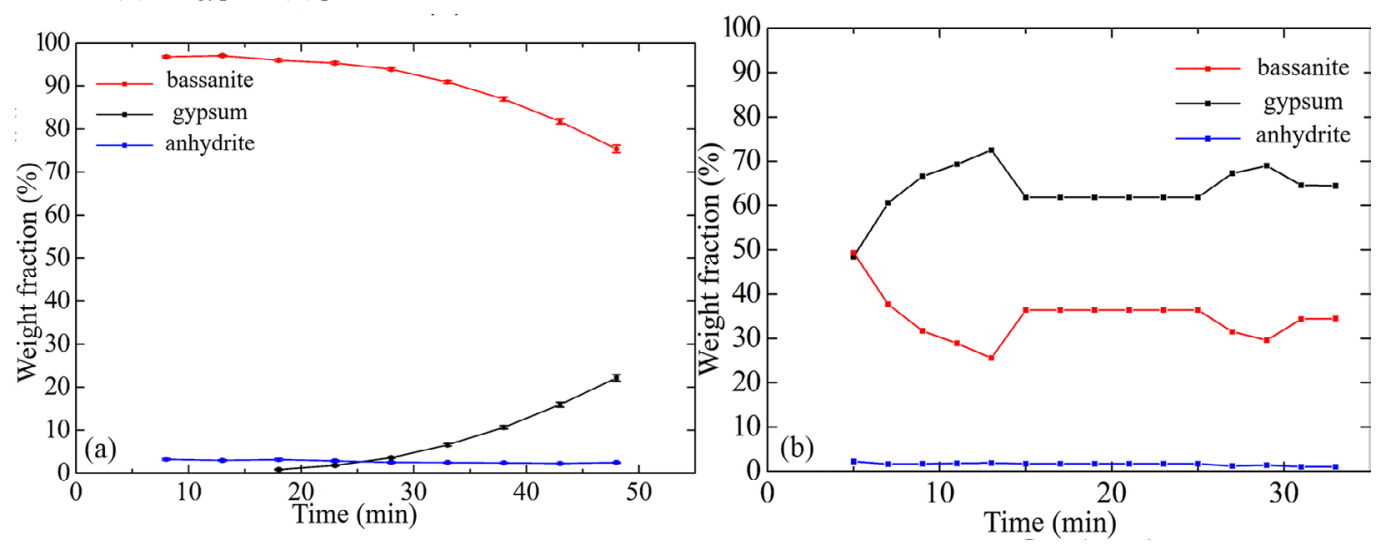

Figure 12. Mass fractions of the sulfate-based compounds (anhydrite - blue dots, bassanite - red dots, and gypsum - black dots) as a function of the hydration time of the samples (a) CP1 and (b) RP1 obtained by the sequential Rietveld refinement.
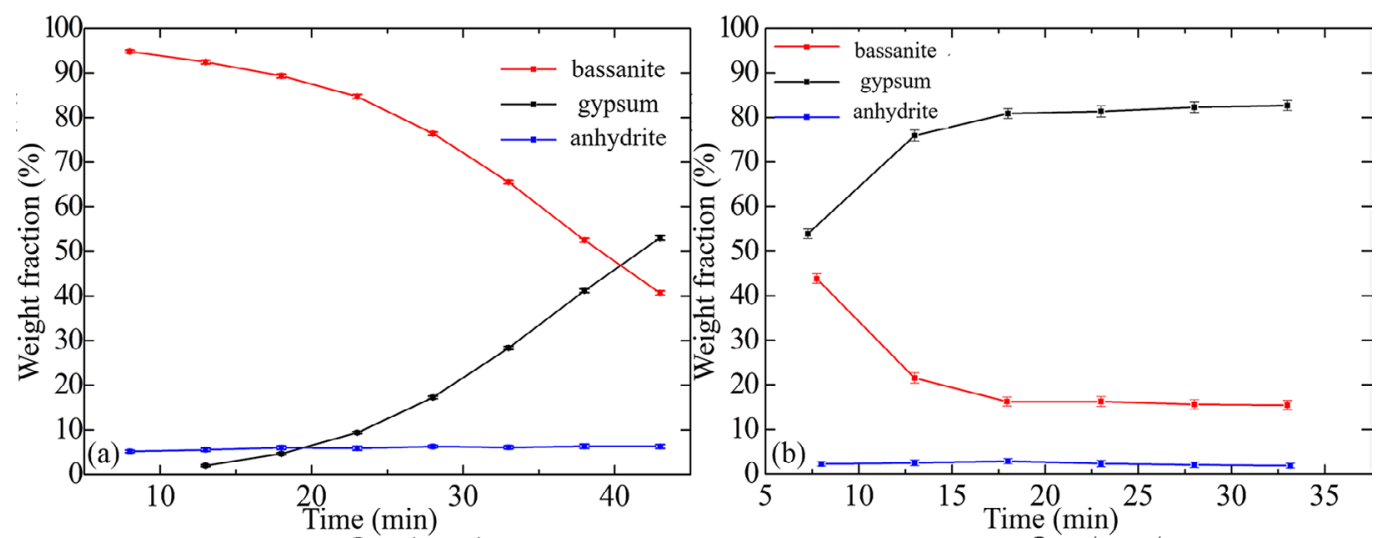

Figure 13. Mass fractions of the sulfate-based compounds (anhydrite - blue dots, bassanite - red dots, and gypsum - black dots) as a function of the hydration time of the samples (a) CP2 and (b) RP2 obtained by the sequential Rietveld refinement. 
In all graphs, the expected behavior of the diffraction profiles as a function of time is observed: as the content of bassanite decreases, the gypsum content increases in the same proportion, but the behavior of the commercial and recycled samples is quite different. For the commercial samples, the predominant phase at the beginning is the bassanite, and the gypsum phase only takes place after 18 minutes - from the contact of the plaster with the water - for the plaster CP1 and after 13 minutes for the plaster $\mathrm{CP} 2$, in both cases in minimum contents. However, in the first measurement of the recycled samples (RP1 and RP2), the gypsum content is almost $50 \%$, proving that the reaction of bassanite with water for the samples with the highest specific surface is instantaneous. For the total time of the experiment, the anhydrite content remained practically constant in all cases, indicating that this is a slow reactivity phase. Also, it is noted that the sequential Rietveld refinement for the RP1 sample did not present an adequate result, which is probably due to the poor counting statistics during data collection, thus making the application of parametric Rietveld refinement of interest.

Thus, the parametric Rietveld refinement was applied to the diffraction data collected during the hydration of the samples from the parameterization of the 11 unit cell parameters of the individual phases (anhydrite, bassanite, and gypsum) using the functions shown in Table 8 - where $t$ is the time of the measurement in seconds - and the results of mass fractions as a function of time are shown in Figure 14 and Figure 15. It can be seen that the behavior of the materials did not change after application of the parametric Rietveld refinement, except for the RP1 sample, which presented the expected behavior in relation to the variation of the mass fraction of the bassanite and gypsum compounds, showing that the method is a powerful tool in the treatment of lower resolution data, since it avoids obtaining a local minimum, without significant changes in the results of sequential refinements that already present appropriate behaviors.

The study of the hydration of gypsum carried out with insitu XRPD data as a function of time allowed us to conclude that the increase of the consistency of the recycled plasters is not only associated to the increase of the microporosity and the specific surface area but also the instant formation of gypsum as soon as the material comes into contact with water. These data also confirm the increase in the kinetic activity values calculated from the results of the temperature kinetics tests, proving that the formation of the hydrated compounds is much faster for the samples of recycled plaster, which is associated with the increase of the area of contact with water.

The quality of the refinements can be evaluated by the $R_{w p}$ index values, which are presented in Figure 16. Note that this index shows similar behavior in the sequential and parametric refinements, thus indicating the consistency of the method.
Table 8.Parameterization functions of the unit cell parameters (a, $\mathrm{b}, \mathrm{c}$, and $\beta$ ) obtained from the sequential Rietveld refinement data

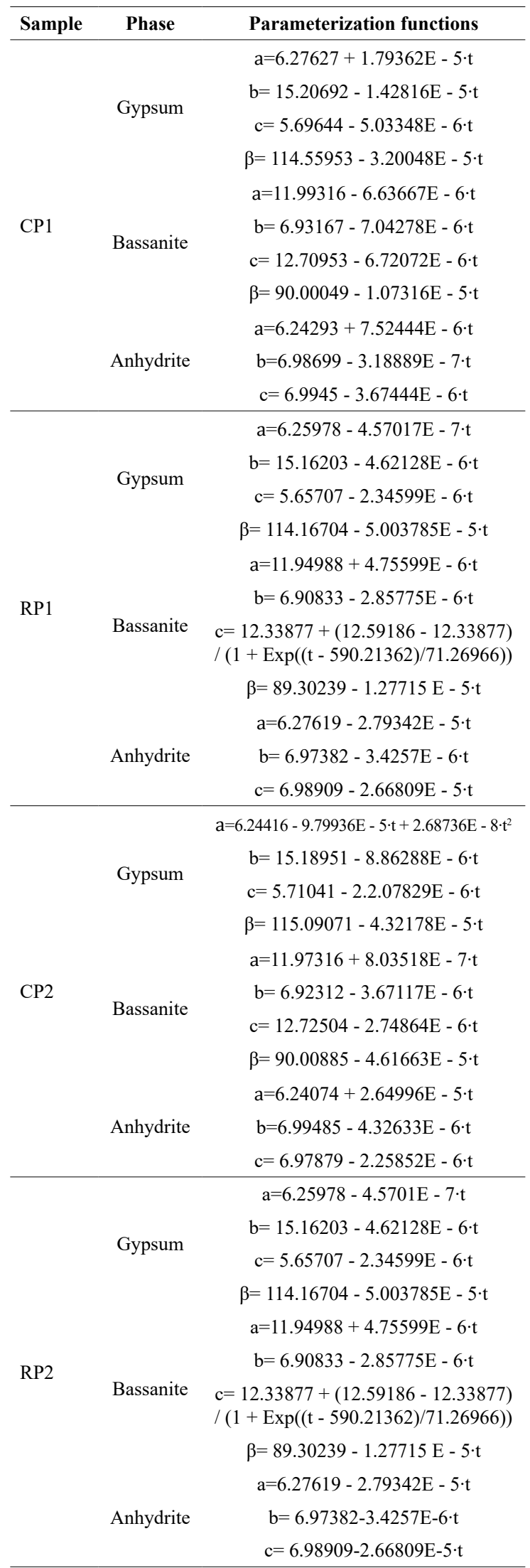



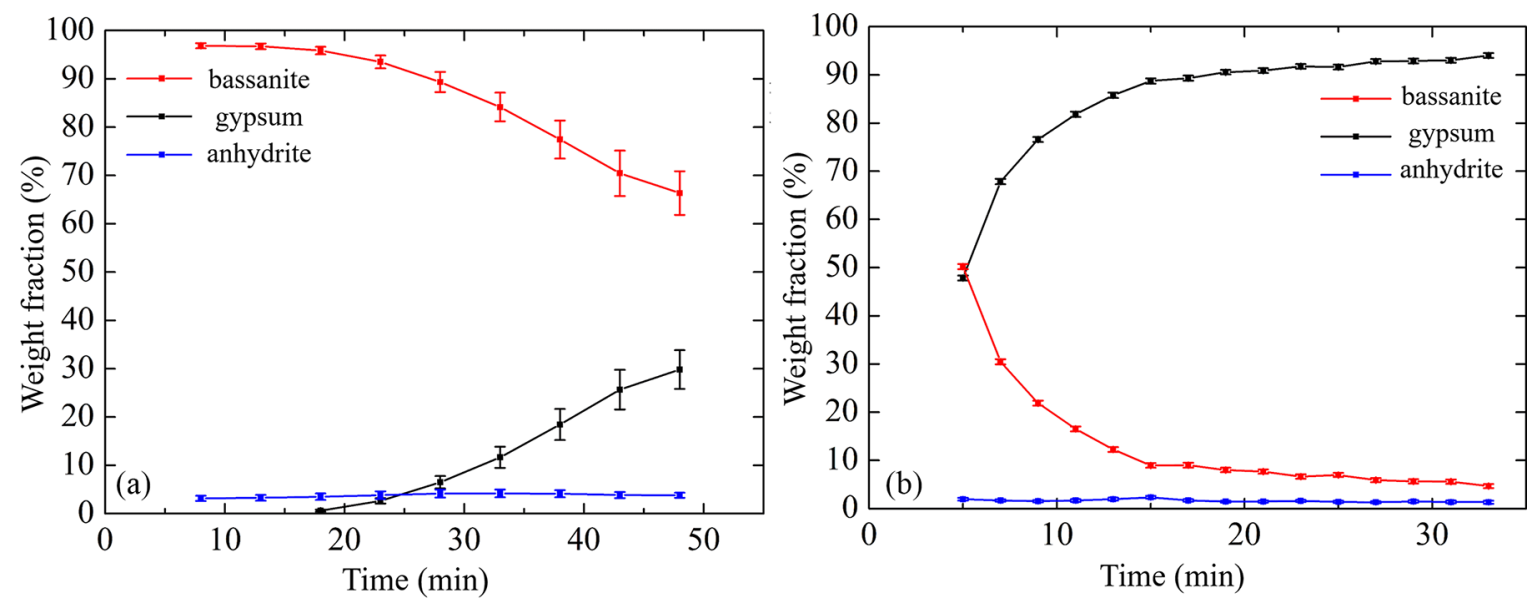

Figure 14. Mass fractions of the sulfate-based compounds (anhydrite - blue dots, bassanite - red dots, and gypsum - black dots) as a function of the hydration time of the samples (a) CP1 and (b) RP1 obtained by the parametric Rietveld refinement.
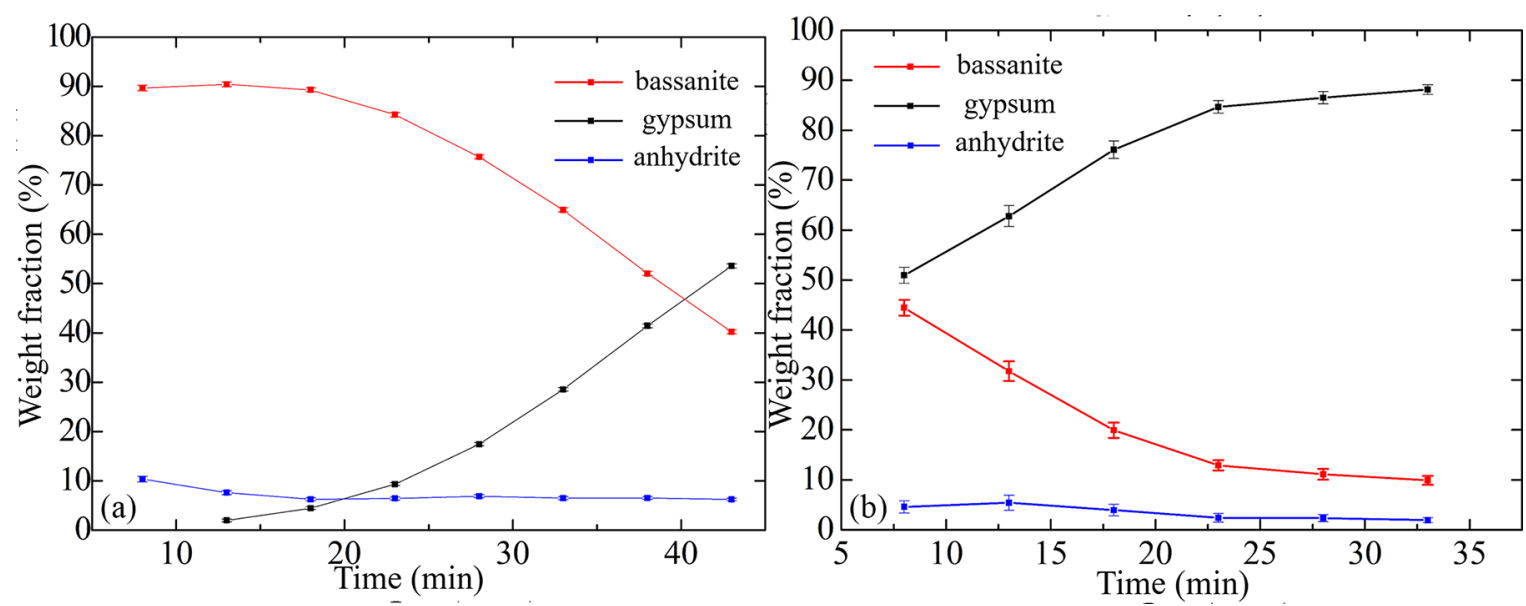

Figure 15. Mass fractions of the sulfate-based compounds (anhydrite - blue dots, bassanite - red dots, and gypsum - black dots) as a function of the hydration time of the samples (a) CP2 and (b) RP2 obtained by the parametric Rietveld refinement.

\subsection{Scanning electron microscopy (SEM)}

Figure 17 shows the scanning electron microscopy images of the hydrated samples. Figure 17a and Figure 17c correspond to the hydrated samples from the commercial plasters, and Figure $17 \mathrm{~b}$ and Figure $17 \mathrm{~d}$ stand for the hydrated samples from the recycled plasters. In general, the pastes obtained with the recycled samples (Figure 17(b and d)) presented very similar aspects among the different plasters, such as gypsum crystals thinner than those of the hydrated samples obtained from the commercial plasters.

Bardella and Camarini ${ }^{55}$ verified by SEM images that the appearance of the hardened gypsum paste from a commercial hemihydrate is very similar to that of the paste produced with recycled hemihydrate, different from what was observed in this work, in which the hardened recycled gypsum presented crystals finer than the hydrated commercial gypsum, probably due to the higher specific surface area of the recycled gypsum in relation to the commercial gypsum.

\section{Conclusions}

The quantitative phase analyses (QPA), coupled with the Rietveld method, proved to be a powerful and adequate tool to study the chemical composition of the plaster, showing that the recycling process did not generate any impact on the chemical composition of the material. All the recycled samples showed a significant increase in their specific surface area and, although the granulometry remained similar to those of the commercial samples, the recycled material increased its microporosity in relation to the commercial material, which also contributes to the surface increase contact information. This inference had a significant impact on the consistency of the recycled material since the amount of water used in the preparation of recycled gypsum pastes was instantly absorbed by the powder. Also, by temperature kinetics and in-situ monitoring of paste hydration, it was observed that this increase in the specific surface area had a high impact on the reactivity of the material. The application of both sequential and parametric Rietveld refinements to model 

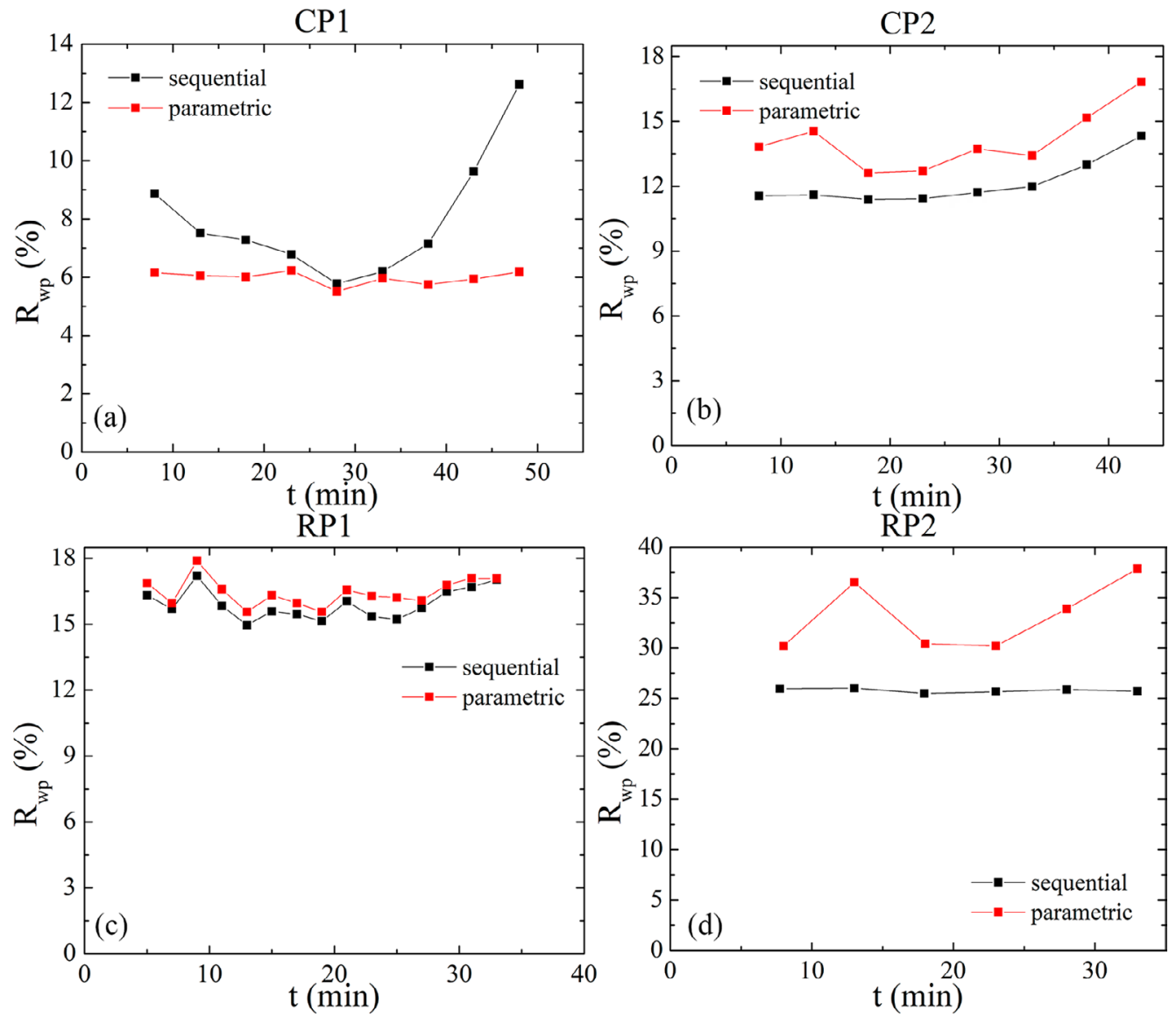

Figure 16. $R_{\text {wp }}$ index behavior in the sequential and parametric Rietveld refinements for the samples (a) CP1, (b) CP2, (c) RP1, and (d) RP2.
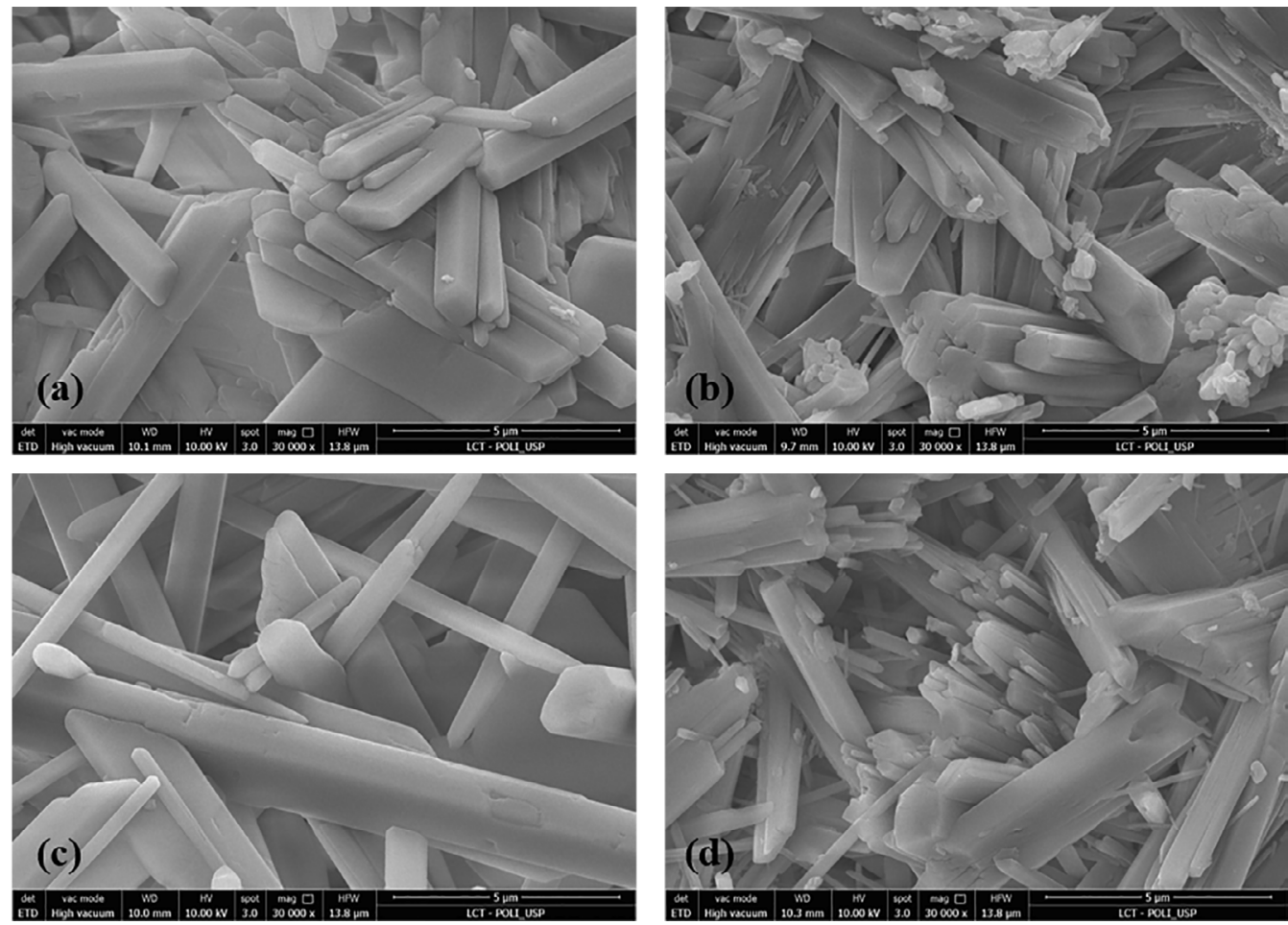

Figure 17. SEM images of hardened gypsum pastes produced from commercial (left) and recycled (right) plasters: (a) HCP1 and (c) HCP2, (b) HRP1, and (d) HRP2. 
the in-situ XRPD data collected to monitor the hydration of the samples allowed us to infer the gypsum formation at the first instants of mixing the recycled samples with the water, proving that the increase of the surface area has led to increased reactivity of the material. The control of the grinding during the recycling process, in relation to the granulometry and micropores, should be monitored in a way to ensure that the recycled material presents a specific surface area similar to the commercial material, since this characteristic influences the reactivity and has impact about the consistency and time of the material, which defines its proper application in works. A practical way of observing the increase of the specific area is the measurement of the compactness of the material since they are inversely proportional measures. Although the recycled plasters did not prove to be applicable in the practical point of view with the water content used in the preparation of the pastes, which could perhaps improve the consistency and retard the hydration reaction, it was concluded that the increase of the specific surface area was a determinant factor in the reactivity of the material.

\section{Acknowledgments}

The authors would like to thank Mauá Institute of Technology for financial support, the Laboratory of Microstructure and Eco-efficiency of Materials (LME), CNPq (grant \# 3076642015-5) and INCT (grant\#2014/50948-3, São Paulo Research Foundation (FAPESP)) and Laboratory of Crystallography and Structural Characterization of Materials (LCCEM UFABC) for the experimental tests.

\section{References}

1. John VM, Cincotto MA. Alternativas de gestão dos resíduos de gesso. São Paulo (SP): Escola Politécnica da Universidade de São Paulo; 2003.

2. Godinho-Castro AP, Testolin RC, Janke L, Corrêa AXR, Radetski CM. Incorporation of gypsum waste in ceramic block production: proposal for a minimal battery of tests to evaluate technical and environmental viability of this recycling process. Waste Management. 2012;32(1):153-7. DOI: http://dx.doi. org/10.1016/j.wasman.2011.08.019

3. Ângulo SC, Miranda LFR, Selmo SMS, Moacyr JV. Reciclagem de entulho para a produção de argamassas e concretos: uma alternativa viável. In: IBRACON, editor. Desenvolvimento sustentável e a reciclagem de resíduos na construção civil. São Paulo: IBRACON; 2001. p. 87-8.

4. Montero A, Tojo Y, Matsuo T, Matsuto T, Yamada M, Asakura $\mathrm{H}$, et al. Gypsum and organic matter distribution in a mixed construction and demolition waste sorting process and their possible removal from outputs. Journal of Hazardous Materials [Internet]. 2010 Mar; 175(1-3):747-53. Available from: https://linkinghub.elsevier.com/retrieve/pii/ S0304389409017233
5. Vrancken KC, Laethem B. Recycling options for gypsum from construction and demolition waste. Waste Management Series [Internet]. 2000; 1:325-31. Available from: https://linkinghub. elsevier.com/retrieve/pii/S0713274300800458

6. Ahmed A, Ugai K. Environmental effects on durability of soil stabilized with recycled gypsum. Cold Regions Science and Technology. 2011;66(2-3):84-92. DOI: http://dx.doi.org/10.1016/j. coldregions.2010.12.004

7. Granholm JM, Chester SE. Drywall recycling. Michigan Department of Environmental Quality. $C \& D$ Recycling Program [Internet]. 2007; [cited 2017 Jan 1]; 1. Available from: http://www.calrecycle.ca.gov/Publications/Documents/ ConDemo/43195069.doc

8. Ministério do Meio Ambiente (BR). Resolução CONAMA n ${ }^{\circ}$ 307, de 05 de julho de 2002. Estabelece diretrizes, critérios e procedimentos para a gestão dos resíduos da construção civil. Diário Oficial da União, Brasília (DF), 17 jul 2002: Seção 1:95-6.

9. Ministério do Meio Ambiente (BR). Resolução n ${ }^{\circ} 431$, de 24 de maio de 2011. Altera o art. $3^{\circ}$ da Resolução $n^{\circ} 307$, de 5 de julho de 2002, do Conselho Nacional do Meio AmbienteCONAMA, estabelecendo nova classificação para o gesso. Diário Oficial da União, Brasília (DF), 25 mai 2011: Seção 1: 123.

10. John VM, Cincotto MA. Gesso de construção civil. In: Materiais de Construção Civil e Princípios de Ciência e Engenhraria de Materiais. $2^{\text {nd }}$ ed. São Paulo: IBRACON; 2007. v. 1. p. 727-60.

11. Pinheiro SMM. Gesso reciclado: avaliação de propriedades para uso em componentes [tese][Internet]. Campinas (SP): Universidade Estadual de Campinas; 2011. Available from: http://pct.capes.gov.br/teses/2011/33003017041P4/TES.PDF

12. Munhoz FC, Renofio A. Uso da gipsita na construção civil $e$ adequação para a $P+L$. In: XXVII Encontro Nacional de Engenharia de Produção. 2007 out 9-11; Foz do Iguaçu, Paraná, Brasil. Foz do Iguaçu (PR): ENEGEP; 2007. p. 2366-85.

13. Camarini G, Pinto MCC, Moura AG, Manzo NR. Effect of citric acid on properties of recycled gypsum plaster to building components. Construction and Building Materials. 2016 Oct;124:383-90. DOI: http://dx.doi.org/10.1016/j. conbuildmat.2016.07.112

14. Karni J, Karni EY. Gypsum in construction: origin and properties. Materials and Structures [Internet]. 1995 Mar; 28(2):92-100. Available from: http://link.springer.com/10.1007/BF02473176

15. Lewry AJ, Williamson J. The setting of gypsum plaster - Part I: The hydration of calcium sulphate hemihydrate. Journal of Materials Science [Internet]. 1994 Oct; 29(20):5279-84. Available from: http://link.springer.com/10.1007/BF01171536

16. Antunes RPN. Estudo da influência da cal hidratada nas pastas de gesso [dissertação]. São Paulo (SP): Universidade de São Paulo; 1999.

17. Solberg C, Hansen S. Dissolution of CaSO $4 \cdot 1 / 2 \mathrm{H} 2 \mathrm{O}$ and precipitation of CaSO $4 \cdot 2 \mathrm{H} 2 \mathrm{O}$ - A kinetic study by synchrotron $\mathrm{X}$-ray powder diffraction. Cement and Concrete Research [Internet]. 2001 Apr; 31(4):641-6. Available from: http://www. sciencedirect.com/science/article/pii/S0008884601004641 
18. Lewry AJ, Williamson J. The setting of gypsum plaster - Part II: The development of microstructure and strength. Journal of Materials Science [Internet]. 1994 Nov; 29(21):5524-8. Available from: http://link.springer.com/10.1007/BF00349943

19. Gmouh A, Eve S, Samdi A, Moussa R, Hamel J, Gomina M. Changes in plaster microstructure by pre-stressing or by adding gypsum grains: microstructural and mechanical investigations. Materials Science and Engineering: A [Internet]. $2003 \mathrm{Jul}$; 352(1-2):325-32. Available from: https://linkinghub.elsevier. com/retrieve/pii/S0921509302009383

20. Song KM, Mitchell J, Jaffel H, Gladden LF. Simultaneous monitoring of hydration kinetics, microstructural evolution, and surface interactions in hydrating gypsum plaster in the presence of additives. Journal of Materials Science [Internet]. 2010 Oct; 45(19):5282-90. Available from: http://link.springer. com/10.1007/s10853-010-4572-7

21. Tydlitát V, Medved' I, Černý R. Determination of a partial phase composition in calcined gypsum by calorimetric analysis of hydration kinetics. Journal of Thermal Analysis and Calorimetry [Internet]. $2012 \mathrm{Jul}$; 109(1):57-62. Available from: http://link. springer.com/10.1007/s10973-011-1334-y

22. Cordon HCF, Cagnoni FC, Ferreira FF. Comparison of physical and mechanical properties of civil construction plaster and recycled waste gypsum from São Paulo, Brazil. Journal of Building Engineering [Internet]. 2019 Mar; 22:504-12. Available from: https://linkinghub.elsevier.com/retrieve/pii/ S2352710218306223

23. Kojima Y, Yasue T. Synthesis of large plate-like gypsum dihydrate from waste gypsum board. Journal of the European Ceramic Society [Internet]. 2006 Jan; 26(4-5):777-83. Available from: https://linkinghub.elsevier.com/retrieve/pii/S0955221905005789

24. Baier T, Dupeux G, Herbert S, Hardt S, Quéré D. Propulsion mechanisms for Leidenfrost solids on ratchets. Physical Review $E$ [Internet]. $2013 \mathrm{Feb}$; 87(2):021001. Available from: http:// arxiv.org/abs/1208.5721

25. Adrien J, Meille S, Tadier S, Maire E, Sasaki L. In-situ X-ray tomographic monitoring of gypsum plaster setting. Cement and Concrete Research. 2016;82:107-16. DOI: http://dx.doi. org/10.1016/j.cemconres.2015.12.011

26. Christensen AN, Olesen M, Cerenius Y, Jensen TR. Formation and transformation of five different phases in the $\mathrm{CaSO}_{4}-\mathrm{H}_{2} \mathrm{O}$ system: crystal structure of the subhydrate $\beta-\mathrm{CaSO}_{4} \cdot 0.5 \mathrm{H}_{2} \mathrm{O}$ and Soluble Anhydrite $\mathrm{CaSO}_{4}$. Chemistry of Materials. 2008 Mar;20(6):2124-32. DOI: http://dx.doi.org/10.1021/cm7027542

27. Styles MJ, Riley DP, Madsen IC, Kisi EH. Parametric Rietveld refinement applied to in situ diffraction studies. In: Conference Handbook, 34 ${ }^{\text {th }}$ Annual Condensed Matter and Materials Meeting; 2010 feb 2-5; Auckland, Australia, New Zealand. Waiheke Island, Auckland: CMM Meeting; 2010. p. 86.

28. Stinton GW, Evans JSO. Parametric Rietveld refinement. Journal of Applied Crystallography [Internet]. 2007 Feb; 40(1):87-95. Available from: http://scripts.iucr.org/cgi-bin/ paper?S0021889806043275
29. Associação Brasileira de Normas Técnicas (ABNT). $N B R$ 12128 - Gesso para construção civil - Determinação das propriedades fisicas da pasta de gesso. Rio de Janeiro: ABNT; 1991. p. 4.

30. Costa FN. Determinação estrutural de derivados n-acilidrazônicos, candidatos a protótipos de fármacos, com o uso da difração de raios $X$ por policristais [dissertação]. Rio de Janeiro: Universidade Federal do Rio de Janeiro / COPPE; 2013.

31. Allmann R, Hinek R. The introduction of structure types into the Inorganic Crystal Structure Database ICSD. Acta Crystallographica Section: A [Internet]. 2007 Sep; 63(A):412-7. Available from: http://scripts.iucr.org/cgi-bin/ paper?S0108767307038081

32. Altomare A, Corriero N, Cuocci C, Falcicchio A, Moliterni A, Rizzi R. QUALX2.0: a qualitative phase analysis software using the freely available database POW_COD. Journal of Applied Crystallography [Internet]. 2015 Apr; 48(2):598-603. Available from: http://scripts.iucr.org/cgi-bin/paper?po5028

33. Gražulis S, Daškevič A, Merkys A, Chateigner D, Lutterotti L, Quirós M, et al. Crystallography Open Database (COD): an open-access collection of crystal structures and platform for world-wide collaboration. Nucleic Acids Research [Internet]. 2012 Jan; 40(D1):D420-7. Available from: https://academic. oup.com/nar/article-lookup/doi/10.1093/nar/gkr900

34. Coelho AA, Evans J, Evans I, Kern A, Parsons S. The TOPAS symbolic computation system. Powder Diffraction [Internet] 2011 Dec; 26(S1):S22-5. Available from: https://www. cambridge.org/core/product/identifier/S0885715600007478/ type/journal_article

35. Associação Brasileira de Normas Técnicas (ABNT). NBR NM 23:2000 - Cimento portland e outros materiais em pó Determinação da massa especifica. Rio de Janeiro: ABNT; 2015. p. 11.

36. Associação Brasileira de Normas Técnicas (ABNT). NBR12127 - Gesso para construção - Determinação das propriedades fisicas do pó. Rio de Janeiro: ABNT; 1991. p. 5.

37. Hunger M, Brouwers HJH. Flow analysis of water-powder mixtures: application to specific surface area and shape factor. Cement and Concrete Composites. 2009;31(1):39-59. DOI: http://dx.doi.org/10.1016/j.cemconcomp.2008.09.010

38. Brunauer S, Emmett PH, Teller E. Adsorption of gases in multimolecular layers. Journal of the American Chemical Society [Internet]. 1938 Feb; 60(2):309-19. Available from: https://pubs.acs.org/doi/abs/10.1021/ja01269a023

39. Potgieter JH, Strydom CA. An investigation into the correlation between different surface area determination techniques applied to various limestone-related compounds. Cement and Concrete Research [Internet]. 1996 Nov; 26(11):1613-7. Available from: https://linkinghub.elsevier.com/retrieve/pii/S0008884696001597

40. Odler I. The BET-specific surface area of hydrated Portland cement and related materials. Cement and Concrete Research [Internet]. 2003 Dec; 33(12):2049-56. Available from: https:// linkinghub.elsevier.com/retrieve/pii/S0008884603002254 
41. Mantellato S, Palacios M, Flatt RJ. Reliable specific surface area measurements on anhydrous cements. Cement and Concrete Research [Internet]. 2015 Jan; 67:286-91. Available from: https://inkinghub.elsevier.com/retrieve/pii/S0008884614002038

42. Munhoz FC. Utilização do gesso para fabricação de artefatos alternativos, no contexto de produção mais limpa [dissertação]. Bauru (SP): Universidade Estadual Paulista; 2008.

43. Bhattacharja S, Tang FJ. Rheology of cement paste in concrete with different mix designs and interlaboratory evaluation of the mini-slump cone test. Portland Cement Associtation. 2000 Jan;2412:121-4.

44. Carvalho MTM, Leles MIG, Tubino RMC. TG and DSC studies on plaster residues as recycled material. Journal of Thermal Analysis and Calorimetry [Internet]. 2008 Feb; 91(2):621-5. Available from: http://link.springer.com/10.1007/s10973-0068169-y

45. Hill RJ, Flack HD. The use of the Durbin-Watson d statistic in Rietveld analysis. Journal of Applied Crystallography [Internet]. 1987 Oct; 20(5):356-61. Available from: http://scripts.iucr.org/ cgi-bin/paper?S0021889887086485

46. Le Bail A, Jouanneaux A. A qualitative account for anisotropic broadening in whole-powder-diffraction-pattern fitting by second-rank tensors. Journal of Applied Crystallography [Internet]. 1997 Jun; 30(3):265-71. Available from: http:// scripts.iucr.org/cgi-bin/paper?S0021889896011922

47. Toby BH. R factors in Rietveld analysis: how good is good enough?. Powder Diffraction [Internet]. 2006 Mar; 21(1):6770. Available from: http://journals.cambridge.org/abstract S0885715600003250

48. Oliveira IR, Studart AR, Pileggi RG, Pandolfelli VC. Dispersão e empacotamento de partículas - Princípios e aplicações em processamento cerâmico [Internet]. $18^{\mathrm{a}}$ ed. São Paulo: Fazendo Arte Editorial; 2000; . Available from: http://www.scielo.br/scielo. php?script=sci_arttext\&pid=S0366-69132001000100013\&ln $\mathrm{g}=\mathrm{pt} \&$ tlng $=\mathrm{pt}$

49. Pye K, Blott SJ. Particle size analysis of sediments, soils and related particulate materials for forensic purposes using laser granulometry. Forensic Science International [Internet]. 2004 Aug; 144(1):19-27. Available from: https://linkinghub.elsevier. com/retrieve/pii/S0379073804001306

50. Gregg SJ, Sing KSW. Adsorption, surface area and porosity. $2^{\text {nd }}$ ed. London: Academic Press; 1982. DOI: http://doi.wiley. com/10.1002/bbpc. 19820861019

51. Lippens B, Boer JH. Studies on pore systems in catalysts $\mathrm{V}$. The $\mathrm{t}$ method. Journal of Catalysis [Internet]. 1965 Jun; 4(3):319-23. Available from: http://linkinghub.elsevier.com/ retrieve/pii/0021951765903076

52. Ye Q, Guan B, Lou W, Yang L, Kong B. Effect of particle size distribution on the hydration and compressive strength development of $\alpha$-calcium sulfate hemihydrate paste. Powder
Technology. 2011 Feb;207(1-3):208-14. DOI: http://dx.doi. org/10.1016/j.powtec.2010.11.001

53. Rossetto JRM, Correia LS, Geraldo RH, Camarini G. Gypsum plaster waste recycling: analysis of calcination time. Key Engineering Materials [Internet]. 2015 Oct; 668:312-21. Available from: http://www.scientific.net/KEM.668.312

54. Ridge MJ, Hill RD. Variations in the rate of hydration of calcium sulphate hemihydrate in gypsum plaster. Australian Journal of Applied Science. 1960;11:180-97.

55. Bardella PS, Camarini G. Hidration crystals by scanning electron microscopy (SEM) in recycled plaster. Activity Report - LNLS. 2007a.

56. Comodi P, Nazzareni S, Zanazzi PF, Speziale S. Highpressure behavior of gypsum: a single-crystal X-ray study. American Mineralogist [Internet]. 2008 Oct; 93(10):1530-7. Available from: https://pubs.geoscienceworld.org/ammin/ article/93/10/1530-1537/44598

57. Schmidt H, Paschke I, Freyer D, Voigt W. Water channel structure of bassanite at high air humidity: crystal structure of $\mathrm{CaSO}_{4} \cdot 0.625 \mathrm{H}_{2} \mathrm{O}$. Acta Crystallographica Section B: Structural Science [Internet]. 2011 Dec; 67(6):467-75. Available from: http://www.ncbi.nlm.nih.gov/pubmed/22101536

58. Bezou C, Nonat A, Mutin JC, Christensen AN, Lehmann MS. Investigation of the crystal structure of $\gamma$-CaSO $4, \mathrm{CaSO} 4$ - $0.5 \mathrm{H} 2 \mathrm{O}$, and $\mathrm{CaSO} 4 \cdot 0.6 \mathrm{H} 2 \mathrm{O}$ by powder diffraction methods. Journal of Solid State Chemistry [Internet]. 1995 Jun; 117(1):165-76. Available from: https://linkinghub.elsevier. com/retrieve/pii/S0022459685712601

59. Höhne E. A more accurate determination of the crystal structure of anhydrite, $\mathrm{CaSO}_{4}$. Soviet Physics - Crystallography. 1963;7(5):559-69.

60. Antao SM, Mulder WH, Hassan I, Crichton WA, Parise JB. Cation disorder in dolomite, $\mathrm{CaMg}\left(\mathrm{CO}_{3}\right)^{2}$, and its influence on the aragonite + magnesite $\leftrightarrow$ dolomite reaction boundary. American Mineralogist [Internet]. 2004 Jul; 89(7):1142-7. Available from: https://pubs.geoscienceworld.org/ammin/ article/89/7/1142-1147/44325

61. Antao S, Hassan I. Temperature dependence of the structural parameters in the transformation of aragonite to calcite, as determined from in situ synchrotron powder X-ray diffraction data. The Canadian Mineralogist. 2010 Oct;48(5):1225-36. DOI: https://doi.org/10.3749/canmin.48.5.1225

62. Le Page Y, Donnay G. Refinement of the crystal structure of low-quartz. Acta Crystallographica Section: B. 1976;32(B):24569. DOI: http://dx.doi.org/10.1107/S0567740876007966

63. Müller-Sommer M, Hock R, Kirfel A. Rietveld refinement study of the cation distribution in ( $\mathrm{Co}, \mathrm{Mg})$-olivine solid solution. Physics and Chemistry of Minerals [Internet]. 1997 Jan; 24(1):17-23. Available from: http://link.springer. com/10.1007/s002690050013 